\title{
REGIONAL TRADE ARRANGEMENTS AND LABOR LIBERALIZATION: (LOST) OPPORTUNITIES FOR EXPERIMENTATION?
}

\author{
KAREN E. BRAVO*
}

PART I-INTRODUCTION

PART II-THE DOMINANT ETHOS: TRADE LIBERALIZATION WITHOUT

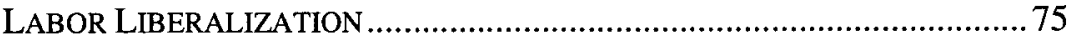

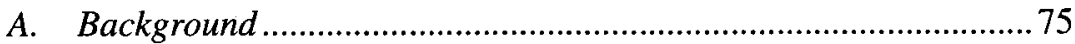

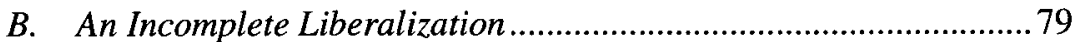

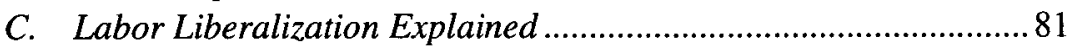

D. Consequences of the Omission of Labor Liberalization .................82 PART III-WESTERN HEMISPHERE REGIONAL TRADE AGREEMENTS:

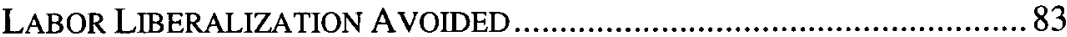

A. General Introduction to Regional Trade Agreements .....................84

1. Espoused Purpose(s) of Regional Trading Arrangements ........84

B. Selected Major Western Hemisphere RTAs ................................... 86

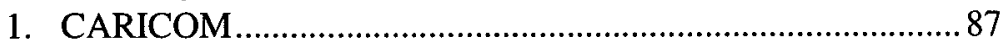

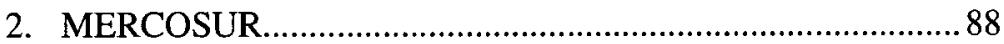

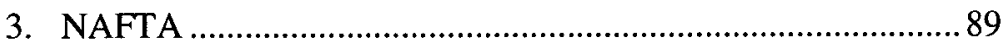

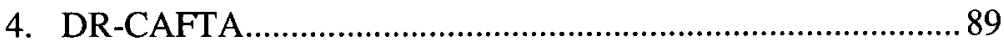

C. Overview of Treatment of Labor Liberalization under the Four Western Hemisphere RTAs................................................90

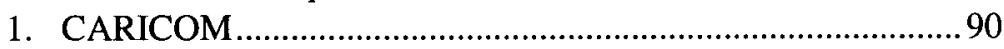

2. MERCOSUR........................................................................ 91

* Associate Professor of Law, Indiana University School of Law - Indianapolis; LL.M. New York University School of Law; J.D. Columbia University School of Law; B.A. University of the West Indies. My thanks to Connie Wagner and the editors of the St. Louis University School of Law Public Law Review for their invitation to participate in the Symposium, as well as to Symposium attendees for their insightful questions and comments. My fellow panelists, Greg Bowman and Elizabeth Trujillo, discussant Janet Koven Levit, and participants at the June 2008 Law and Society Annual Meeting provided thought-provoking comments and feedback to the ideas explored in the article. My colleague, Dan Cole, offered interest, encouragement and sources. My colleagues, Maria Pabón Lopez and R. George Wright; Tequila Brooks, LL.M. candidate George Washington University Law School and former labor law advisor, Commission for Labor Cooperation Secretariat; Dean Kevin R. Johnson; and Ian S. McIntosh gave helpful comments on early drafts. I am grateful for Afshan Paarlberg's research assistance. 


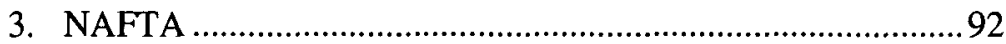

4. DR-CAFTA......................................................................93

D. Analysis of Treatment of Labor under the Four Western

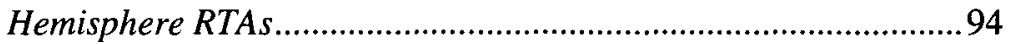

PART IV - BARRIERS TO LABOR LIBERALIZATION ........................................96

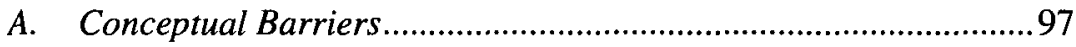

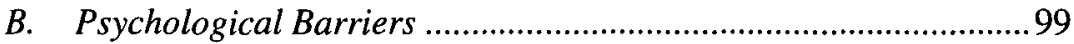

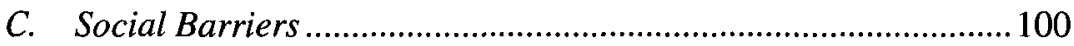

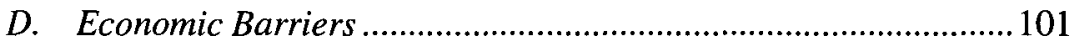

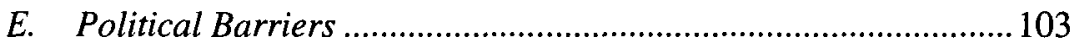

PART V-EXPERIMENTING WITH LABOR LIBERALIZATION NOW?

PROSPECTS FOR THE FUTURE ........................................................... 105

A. Effects of Failure to Liberalize Labor........................................106

1. On RTAs Generally ...........................................................106

2. On RTAs in the Western Hemisphere...................................107

B. RTAs Provide Excellent Opportunity for Experimentation ........... 108

1. Existing Examples of Successful Experimentation.................109

C. Labor Liberalization Now? ........................................................... 110

PART VI-CONCLUSION: THE WAY FORWARD ............................................113

\section{PART I-INTRODUCTION}

The contemporary globalization project is facilitated and stimulated in large part by multilateral trade liberalization. ${ }^{1}$ In tandem with-and sometimes as an alternative to-stalled multilateral trade negotiations, states rush to enter into a veritable explosion of regional trade arrangements (RTAs). ${ }^{2}$ The trade

1. As used in this article, globalization means the increasing interdependence, interconnection and intertwining of the economies of individual states. While globalization is not new (throughout centuries of human history successive waves of globalization have brought different regions of the world in greater contact-for example, Africa, the Western Hemisphere and Europe were brought in closer contact via the trans-Atlantic slave trade), the technological advances of the twentieth and twenty-first centuries have quickened and deepened the relationships among widely dispersed states.

2. Article XXIV of the General Agreement on Tariffs and Trade, Oct. 30, 1947, 61 Stat. pts. 4, 55 U.N.T.S. 194 [hereinafter GATT 1947], provides that member states may enter into regional trading arrangements without violating obligations under the GATT so long as certain provisions are followed. As of July 2008, 380 RTAs had been notified to the World Trade Organization (WTO). According to the WTO web site, close to 400 RTAs are scheduled for implementation by 2010. See Regional Trade Agreements, http://wto.org/english/tratop_e/region _e/region_e.htm (last visited Oct. 5, 2008).

The General Agreement on Tariffs and Trade (in Annex 1A to the WTO - Multilateral Trade Agreements on Goods), Apr. 15, 1994, 33 I.L.M. 1125 [GATT 1994], incorporates GATT 1947 , as well as legal instruments set forth in GATT 1994 which had entered into force pursuant to GATT 1947 prior to the entry into force of the Agreement Establishing the World Trade 
liberalization begun at Bretton Woods, enhanced by successive rounds of negotiations, ${ }^{3}$ and to which much of the world is now committed, ${ }^{4}$ is focused on lowering barriers to the movement of goods, capital, services and ideas, including legal cultures. ${ }^{5}$ Trade theorists and supporters of free trade claim that liberalization of the movement of goods, capital, services and ideas stimulates efficient, competitive and productive economic activity that will ultimately accrue to the benefit of all participants. Yet, the liberalization of labor (and the consequent movement of human beings) is a neglected and feared aspect of multilateral and regional trade liberalization policies and agreements.

Despite deeply held concerns and the expected difficulty of transition, labor liberalization is a necessary and inevitable aspect of trade liberalization. ${ }^{6}$ Contrary to the assumptions underlying the structure of the contemporary model of trade liberalization, labor liberalization is not called for only in the context of deepened regional integration-specifically the formation of a common market. $^{7}$ On the contrary, if all participating economies and economic actors are to experience the promised benefits of trade liberalization so as to harness economic theory and forces for the benefit of a broader constituency, including human labor, then labor liberalization must be recognized and facilitated as an integral part of trade liberalization. ${ }^{8}$

Organization, April 15, 1994, 33 I.L.M. 1125 (1994) [hereinafter the WTO Agreement]. Unless specific reference is made to GATT 1947 or GATT 1994, references to "the GATT" include both GATT 1947 and GATT 1994, as well as the institutional framework created pursuant to the agreements.

3. The structured multilateral negotiations conducted by GATT members have addressed and attempted to remove or minimize innumerable barriers to trade liberalization. The first eight rounds of negotiations culminated with the formation of the World Trade Organization, among other trade liberalization achievements. See RAJ BHALA \& KEVIN KENNEDY, WORLD TRADE LAW: THE GATT-WTO SYSTEM, REgIONAL ARRANGEMENTS AND U.S. LAW 5-7 (1998). The member states have missed the targeted completion dates of the current round of negotiations, the Doha Development Round, but negotiations continue to be held. See, e.g., The Doha Agenda, http://www.wto.org/english/thewto_e/whatis_e/tif_e/dohal_e.htm (last visited Oct. 5, 2008).

4. As of May 16, 2008, 152 of the world's 192 states have acceded to the WTO. See Ukraine Becomes the WTO's 152nd Member, http://www.wto.org/english/news_e/news08_e/ acc_urk_may08_e.htm (last visited Oct. 5, 2008).

5. The Uruguay Round of negotiations that resulted in the creation of the World Trade Organization added the liberalization of trade in services and the recognition and enforcement of a U.S.-dominated conception of intellectual property rights.

6. See infra Part II.C (elaborating this article's concept of labor liberalization, which seeks to liberate labor from conceptual and constructed constraints on mobility).

7. The European Union is the quintessential example of labor liberalization in the context of the creation of a common market.

8. It is the achievement of human rights standards, which includes labor rights, that must be the end goal of labor (and trade) liberalization. Standing alone, the liberalization of labor within the context of trade liberalization cannot achieve the equitable distribution of the benefits to be 
Labor is one of the basic factors of production identified in classical and neoclassical economic theory. In the face of the economic distortions that stem from the neglect of the liberalization of this fundamental input of economic production, trade liberalization cannot succeed in its espoused purpose of increased economic efficiency and productivity and enhanced standard of living benefits That neglect has not succeeded in preventing the movement of labor (people) attempting to respond to the economic incentives and disincentives arising from trade liberalization and the forces of globalization. Instead, the intertwined neglect and prohibition of labor liberalization by state parties to multilateral and regional trade liberalization treaties create and maintain incentives that drive underground and form the basis of illicit exploitative markets that are sustained by the obstructed movement of labor.

Regional trading arrangements, which create trade groupings of small numbers of neighboring member states with greater homogeneity of cultures, economies and interests, would appear to provide opportunities for experimentation in this neglected area of the contemporary multilateral trade liberalization and globalization project. However, with the remarkable exception of the European Union, states have failed to take advantage of the opportunity to experiment with labor liberalization even within the more controlled context of regional trading arrangements.

Instead, state participants in regional trading arrangements appear to contemplate the liberalization of labor solely within the context of a drive toward deeper integration of member state economies. ${ }^{9}$ In the Western Hemisphere, even within the context of planned enhanced integration of economies and proposed labor liberalization initiatives, the implementation of labor liberalization is a stillborn part of a rhetoric that has not yet become actuality. However, the benefits anticipated from the efforts toward the liberalization of the movement of goods, services and capital are incomplete where the liberalization of labor is not also undertaken.

The commitments made toward labor liberalization within regional trading arrangements in the Western Hemisphere have, to date, been timid in

gained from trade liberalization. Labor liberalization must be implemented in tandem with the formation and enforcement of human rights standards. The right of labor to exit and enter domestic markets will strengthen labor's ability to enforce adherence to labor and other human rights standards.

9. That is, only within the context of the creation of a common market, such as the European Union's freedom of movement for member state nationals. RTAs are usually characterized as free trade areas, customs unions and common markets. See, e.g., Karen E. Bravo, CARICOM, the Myth of Sovereignty and Aspirational Economic Integration, 31 N.C. J. INT'L L. \& COM. REG. 145, 156-57 (2005) (discussing these typologies). RTAs can also be distinguished according to other metrics, such as the type of regional institution building, the creation of or failure to create regional institutions with supranational legal personality and the types and effectiveness of dispute resolution procedures, as well as other factors. 
conceptualization and half-hearted in execution due in part to economic, social, political and conceptual barriers. This article examines the treatment of labor liberalization in four key regional trading arrangements in the Western Hemisphere: the Caribbean Community (CARICOM), the Common Market of the Southern Cone (MERCOSUR), the North American Free Trade Agreement (NAFTA), and the Dominican Republic-Central American Free Trade Agreement (DR-CAFTA). This article also identifies the consequences of the failure to address this key aspect of trade liberalization.

Part II briefly summarizes the contemporary multilateral trade liberalization project with a focus on the neglect of labor liberalization. Part III examines the rhetoric and reality of labor liberalization in the four major Western Hemisphere regional trading arrangements, while Part IV identifies and analyzes the barriers to execution of such liberalization. Part V posits that the opportunities to experiment with labor liberalization in the Western Hemisphere within regional trading arrangements are not irrevocably lost. The conclusion summarizes the prospects and prerequisites for liberalization of labor in the hemisphere and acknowledges prospective implementation and transitional challenges.

\section{PART II-THE DOMINANT ETHOS: TRADE LIBERALIZATION WITHOUT LABOR LIBERALIZATION}

\section{A. Background}

David Ricardo's theory of comparative advantage, ${ }^{10}$ bolstered by the Hecksher-Ohlin theory's insights regarding the role of factor endowments in framing the comparative advantage of individual economies, ${ }^{\text {" forms the }}$ theoretical foundation of contemporary multilateral and regional trade liberalization. According to Ricardo, each producer (and economy) should focus on the production of goods in which it has a comparative advantage visà-vis its trading partners. ${ }^{12}$ Hecksher-Ohlin added the insight that differences in factor endowments—land, labor, capital-largely determined each economy's comparative advantage and, therefore, the productive activities in which participating economies should engage. ${ }^{13}$ It naturally flows from the identification of an economy's comparative advantage, the logic of the theory of comparative advantage, and the understanding of factor endowments, that overall welfare will be increased when economies trade with each other to

10. See, e.g., Robert Gilpin, The Political Economy of INTERnational Relations 172-74 (1987) (discussing and explaining David Ricardo's theory of comparative advantage).

11. See generally BERTIL OHLIn, InTERregional and INTERNATIONAL TRADE (1935). Ohlin's work rests in part on that of Eli Heckscher, hence the designation of "Hecksher-Ohlin."

12. GILPIN, supra note 10, at 173-174.

13. See generally OHLIN, supra note 11. 
obtain the products that their individual factor endowments do not allow them to produce as efficiently and cheaply as do their trading partners. ${ }^{14}$ By trading and lowering barriers to trade among producers, factor endowments are more efficiently utilized by the economic actors, both individually and as a group, prices are lowered through competition and consumer choice is enhanced.

GATT $1947^{15}$ and the Uruguay Round Marrakesh Agreement Establishing the World Trade Organization ${ }^{16}$ are multilateral implementations of these theories. ${ }^{17}$ Under GATT 1947, the Bretton Woods negotiators put in place legal mechanisms to liberalize the movement of goods among signatory states and instituted a negotiating apparatus for the successive lowering of tariffs and non-tariff barriers to the movement of such goods. ${ }^{18}$ The Uruguay Round of negotiations exponentially expanded the subjects and spheres of influence of the trade liberalization ethos by encompassing the liberalization of capital, services and legal concepts. ${ }^{19}$

14. See, e.g., Stephen Redding, Dynamic Comparative Advantage and the Welfare Effects of Trade, 51 OXFORD ECONOMIC PAPERS 15, 17 (1999), available at http://oep.oxfordjournals.org/ cgi/reprint/51/1/15.

15. GATT 1947 , supra note 2.

16. See the WTO Agreement, supra note 2. Major achievements of the Uruguay Round included the formation of the Agreement on Technical Barriers to Trade, Apr. 15, 1994, Marrakesh Agreement Establishing the Word Trade Organization, Annex 1A, 33 I.L.M. 1125 (1994), available at http://www.wto.org/English/docs_e/legal_e/17-tbt.pdf, and Agreement on the Application of Sanitary and Phytosanitary Measures, id, available at $\mathrm{http}: / / \mathrm{www}$.wto.org/english/ docs_e/legal_e/15-sps.pdf., both of which attack specific types of non-tariff barriers.

17. Pursuant to the WTO Agreement, GATT 1947 continues in force as a multilateral annex to the WTO Agreement. See BHALA \& KENNEDY, supra note 3, at 8-12 (discussing and summarizing the legal mechanisms of the transition from the GATT to the WTO, and the incorporation of GATT obligations into the WTO regime).

18. The International Trade Organization, the stillborn institutional trade liberalization equivalent of the International Monetary Fund and World Bank for Reconstruction and Development, was to have oversight duties for the interpretation of the GATT. See United Nations Conference on Trade and Employment, Mar. 24, 1948, Havana Charter for an International Trade Organization [hereinafter Havana Charter], available at http://www.world tradelaw.net/misc/havana/pdf. Cold War tensions prevented the formation of the ITO. See Paul Demaret, The Metamorphoses of the GATT: From the Havana Charter to the World Trade Organization, 34 COLUM. J. TRANSNAT'L L. 123, 125-27 (1996).

19. For example, the Agreement on Trade-Related Aspects of Intellectual Property Rights art.1, Apr. 15, 1994, Marrakesh Agreement Establishing the World Trade Organization, Annex 1C, 33 I.L.M. 81 (1994) [hereinafter TRIPS Agreement], available at http://www.wto.org/ english/docs_e/legal_e/27-trips.pdf, exported to all WTO member states the concepts of intellectual property that had evolved in the Western World. See, e.g., Ruth L. Gana, Has Creativity Died in the Third World? Some Implications of the Internationalization of Intellectual Property, 24 DENV. J. INT'L L. \& POL'Y 109, 111-12 (1995); J.H. Reichman, Universal Minimum Standards of Intellectual Property Protection Under the TRIPS Component of the WTO Agreement, 29 INT'L LAW 345, 347 (1995). 
In order to multi-lateralize the effects and endeavors of trade liberalization, the adherents to GATT 1947 (and, subsequently, the member states of the WTO) undertake to extend the trade preferences conferred on any single member state or other trading partner to all member states. ${ }^{20}$ The mechanisms employed are the nondiscrimination obligations of national treatment and most favored nation, which require that the member states treat the goods and services of other member states no less preferentially than domestic goods and services are treated. ${ }^{21}$ In effect, each state party agrees to allow the goods and services of WTO member states to compete within its territory on an equal footing with one another and with the domestically produced "like," substitutable and/or competitive products and services. ${ }^{22}$

20. GATT 1947, supra note 2, art. I, $\S 1$. Article I of GATT 1947 spells out the most favored nation obligation of member states:

With respect to customs duties and charges of any kind imposed on or in connection with importation or exportation or imposed on the international transfer of payments for imports or exports, and with respect to the method of levying such duties and charges, and with respect to all rules and formalities in connection with importation and exportation, and with respect to all matters referred to in paragraphs 2 and 4 of Article III, any advantage, favour, privilege or immunity granted by any contracting party to any product originating in or destined for any other country shall be accorded immediately and unconditionally to the like product originating in or destined for the territories of all other contracting parties.

Id.

21. Id. art. III, $\S \S 1,2$. Article III of GATT 1947 lays out the National Treatment obligation. Article III, section 1 and 2 specify that:

1. The contracting parties recognize that internal taxes and other internal charges, and laws, regulations and requirements affecting the internal sale, offering for sale, purchase, transportation, distribution or use of products, and internal quantitative regulations requiring the mixture, processing or use of products in specified amounts or proportions, should not be applied to imported or domestic products so as to afford protection to domestic production.

2. The products of the territory of any contracting party imported into the territory of any other contracting party shall not be subject, directly or indirectly, to internal taxes or other internal charges of any kind in excess of those applied, directly or indirectly, to like domestic products. Moreover, no contracting party shall otherwise apply internal taxes or other internal charges to imported or domestic products in a manner contrary to the principles set forth in paragraph 1.

Id.

22. The jurisprudence of the WTO Appellate Body has fleshed out the criteria for likeness, substitutability and nondiscrimination under the provisions of GATT 1947 and GATT 1994. See, e.g., Appellate Body Report, Japan-Taxes on Alcoholic Beverages, WT/D58/AB/R, WT/DS10/AB/R, WT/DS11/AB/R (Oct. 4, 1996); WTO Appellate Body Report, Korea-Taxes on Alcoholic Beverages, WT/DS75/AB/R, WT/DS84/AB/R (Jan. 18, 1999); Appellate Body Report, Chile-Taxes on Alcoholic Beverages, WT/DS87/AB/R, WT/DS110/AB/R (Dec. 13, 1999). 
A key exception to the non-discrimination doctrines is found in Article XXIV of GATT 1947, which allows states parties to GATT 1947 (and subsequently, WTO member states) to enter into regional trading arrangements such as common markets, customs unions and free trade areas. ${ }^{23}$ Pursuant to the exception, the member states may extend more preferential treatment to members of the regional trading arrangement (in seemingly blatant violation of the GATT's non-discrimination provisions) so long as the net impact on trade with the remaining member states who are non-parties to the regional trading arrangements is not negative. ${ }^{24}$ Additionally, all such regional trading arrangements are to be notified to and examined by the WTO. ${ }^{25}$

\section{Article XXIV, sections 4 and 5 of GATT 1947 state:}

4. The contracting parties recognize the desirability of increasing freedom of trade by the development, through voluntary agreements, of closer integration between the economies of the countries parties to such agreements. They also recognize that the purpose of a customs union or of a free-trade area should be to facilitate trade between the constituent territories and not to raise barriers to the trade of other contracting parties with such territories.

5. Accordingly, the provisions of this Agreement shall not prevent, as between the territories of contracting parties, the formation of a customs union or of a free-trade area or the adoption of an interim agreement necessary for the formation of a customs union or of a free-trade area....

GATT 1947, supra note 2, art. XXIV, $\S \S, 4,5$. See infra Part III.A (discussing different types of regional trading arrangements).

24. Article XXIV, sections 5(a) and 5(b) of GATT 1947 specify that the creation of the RTA shall not impose new or additional barriers to trade for member states not party to the RTA:

(a) with respect to a customs union, or an interim agreement leading to a formation of a customs union, the duties and other regulations of commerce imposed at the institution of any such union or interim agreement in respect of trade with contracting parties not parties to such union or agreement shall not on the whole be higher or more restrictive than the general incidence of the duties and regulations of commerce applicable in the constituent territories prior to the formation of such union or the adoption of such interim agreement, as the case may be;

(b) with respect to a free-trade area, or an interim agreement leading to the formation of a free-trade area, the duties and other regulations of commerce maintained in each of the constituent territories and applicable at the formation of such free-trade area or the adoption of such interim agreement to the trade of contracting parties not included in such area or not parties to such agreement shall not be higher or more restrictive than the corresponding duties and other regulations of commerce existing in the same constituent territories prior to the formation of the free-trade area, or interim agreement as the case may be....

GATT 1947, supra note 2, art. XXIV, §§ 5(a)-(b).

25. Id. art. XXIV \& 7(a). Member states are required to inform the WTO of their formation of and/or participation in RTAs. Article XXIV, section 7(a) of GATT 1947 specifies that:

[a]ny contracting party deciding to enter into a customs union or free-trade area, or an interim agreement leading to the formation of such a union or area, shall promptly notify the Contracting Parties and shall make available to them such information regarding the 
As a consequence of the exception provided by Article XXIV, regional trading arrangements (and thus, regional trade liberalization) have flourished alongside the multilateral trade liberalization encapsulated in and stimulated by the GATT/WTO system. Seemingly counter intuitively, ${ }^{26}$ the period following the successful completion of the Uruguay Round of trade negotiations and formation of the WTO has witnessed a remarkable increase in the creation of regional trading arrangements. ${ }^{27}$

\section{B. An Incomplete Liberalization}

Throughout this process of continual liberalization, the fundamental and mostly unspoken underlying concept of labor as an immobile factor of production (truly analogous to immobile land) has not been institutionally challenged. $^{28}$ The multilateral trade liberalization undertaken through the WTO and most examples of regional trade liberalization (with the marked exception of the European Union) have neglected the liberalization of labor. That neglect betrays both fundamental trade liberalization theory and classical and neoclassical economic theory.

proposed union or area as will enable them to make such reports and recommendations to

contracting parties as they may deem appropriate.

Id. See also Chi Carmody, Metrics and the Measurement of International Trade: Some Thoughts on the Early Operation of the WTO RTA Transparency Mechanism, 28 ST. LOUIS PUB. L. REV. 273 (2008) (discussing and analyzing the operation of the Uruguay Round notification obligations).

26. The post-WTO increase in the formation of RTAs is counterintuitive in light of the volume of trade affected by negotiated gains in the liberalization of trade attained through the Uruguay Round. Yet the increasing resort to RTAs by member states representing every stage of economic development suggests, among possible explanations, that the Uruguay Round achievements do not satisfy the trading needs of the member states, that greater liberalization can be achieved through RTAs, or that the factors driving the increase in RTA formation are not solely related to trade considerations.

27. Compare the number of notifications for RTAs that preceded the WTO with the number of notifications that have followed the WTO's formation. See Regional Trade Agreements: Facts and Figures, http://www.wto.org/english/tratop_e/region_e/regfac_e.htm (displaying WTO chart depicting the post-1994 surge in notifications of RTAs to the WTO) (last visited Oct. 5, 2008).

28. Some developing countries have attempted to raise this issue in the context of the General Agreement on Trade in Services, Apr. 15, 1994, Marrakesh Agreement Establishing the World Trade Organization, Annex 1B, Results of the Uruguay Round, 33 I.L.M. 283 [hereinafter GATS], a multilateral annex to the WTO Agreement to which all WTO members must adhere, but with limited success. See, e.g., Joy Kategekwa, Extension of Mode 4 Commitments to Include Unskilled Workers in the WTO. A Win-Win situation, Especially for LDCs, Address at the OECD Development Centre Panel on Migration and Development (Sept. 25-26, 2006), available at http://www.oecd.org/dataoecd/5/26/37501680.pdf (discussing requests of less developed countries within the WTO negotiation frameworks to broaden the scope of GATS Mode 4 provisions governing the provision of services through the presence of natural persons in line with those countries' comparative advantage). 
Pursuant to classical and neoclassical theory, labor is one of the principal factors of production. ${ }^{29}$ Trade liberalization theory touts the welfare enhancing benefits that are to be gained through removal of barriers to the movement of both factor inputs (such as capital) and finished and unfinished products or goods. However, the movement of labor, a fundamental production input, is ignored. Instead, dominant trade liberalization policy efforts assume, without examination, the immobility of labor as a factor of production. At the same time, mass migratory movements by labor representing all levels of skills ${ }^{30}$ reveal a deep disjuncture between the rhetoric and reality of trade liberalization.

Through the mechanism of trade liberalization, economic forces and actors are unleashed to act trans-nationally and globally. At the same time, via neglect in trade liberalization policies and active construction of barriers, states and some vested interests oppose and encumber the movement of labor. That neglect constrains the ability of both individual workers and labor acting collectively to respond fully to transnational economic stimuli or to participate actively in globalization as autonomous economic actors.

Moreover, because labor may not easily undertake transnational movement to either exit or enter individual domestic markets, this blind spot in trade liberalization also stymies the ability of individual states to flexibly adjust the factor inputs into their domestic economic production in response to changes in the demand for labor. ${ }^{31}$ Labor liberalization would allow the unemployed in a

29. The other classical factors of production are capital and land. Additional inputs into production include entrepreneurship and technology. Labor, of course, differs from the other factors of production by virtue of its humanity and is more than a mere input into production. The failure of the contemporary trade liberalization project to recognize and implement labor's equal status as a factor of production and to deploy a holistic economic conceptualization of labor undermines the trade liberalization project. See discussion infra Part IV.A.

30. See, e.g., INTERNATIONAL MIGRATION OUTLOOK: SOPEMI-2007 EDITION 132-134 (OECD2007) (discussing and charting the education levels of immigrants to OECD countries for the years 2003-2004).

31. Worthy of further investigation but beyond the scope of this article is the question whether the treatment of labor under the contemporary trade liberalization model betrays the lingering influence of mercantilist sentiments in the mindset of nation state policymakers (and, indeed, of trade theorists). Is the modern state's retention and "ownership" of labor originating within state borders a vestige of the mercantilist hoarding of "specie"? See, e.g., ROBERT B. Ekelund, JR. \& ROBERT D. TOllison, POltTiCized ECONOMIES: MONARChY, MONOPOly, AND MERCANTILISM 4 (1997) ("Among the most often stressed tenets of the mercantilists are the equation of specie with wealth, regulation of the trade sector to produce specie inflow, and emphasis upon population growth and low wages."); R.J. BARRY JONES, CONFLICT AND CONTROL IN THE WORLD ECONOMY: CONTEMPORARY ECONOMIC REALISM AND NEOMERCANTILISM 10 (1986) (describing "classical mercantilism" as being "primarily 'bullionist'; policy being directed toward the accumulation of bullion, specie and all other readily transportable forms of wealth..."). 
labor-rich economy to find employment in labor-poor economies where such employment openings may otherwise not have been filled. At the same time, a labor-poor economy engaged in labor-intensive production would be able to increase the availability of labor through labor liberalization policies that welcome the influx of new labor. ${ }^{32}$

The failure to challenge the assumed immobility of labor flies in the face of evidence of the adjustability and mutability of factor inputs and of comparative advantage. For example, state intervention in adjusting the quality, nature or characteristics of factor endowments may fundamentally alter an economy's comparative advantage. ${ }^{33}$ Alternatively, an economy that is rich in labor but poor in capital may, through the import of capital, transform its comparative advantage from production of low-capital to more sophisticated capital-intensive products. ${ }^{34}$ In both cases, the flexibility and ease of adoption of different policies by individual economies would be enhanced by the liberalization of labor. Furthermore, the increasing interdependence of economies would be openly acknowledged in political and economic discourse and policy making.

\section{Labor Liberalization Explained}

In the context of multilateral trade liberalization as currently implemented, labor is conceptualized as subordinate to and/or subsumed within the production of goods and services. The labor liberalization advocated here would not commoditize labor in order to facilitate its increased exploitation in economic activity by other actors, such as states or other entities. Instead, this article's advocacy of the liberalization of labor within the broader trade liberalization project would free labor on three levels: First, labor would be liberalized from its current conceptualization as a mere immobile input into the production of goods and services. Second, labor would be liberalized from the state border constraints that have sought to limit its trans-border movement and have therefore rendered it more easily exploited. As an autonomous economic unit, labor could seek out the markets where demand is highest and labor is most highly valued and compensated. Third, labor liberalization would

32. An obvious example is the United States throughout most of its history: African slaves, European immigrants (including indentured servants) and Asian and Latino laborers have provided a much-needed and frequently involuntary labor supply during various eras.

33. Or, through government intervention in education, for example, an economy's qualitative comparative advantage in labor may be transformed from low-skilled to high-skilled labor.

34. Similarly, through the import of technology and/or capital, an economy that is not amply endowed with land may nevertheless efficiently utilize its land acreage for production of goods that are more typically produced by an economy that is richly endowed with land as a factor of production. 
democratize access to the benefits of trade liberalization by increasing labor's opportunities to seek out the newly created economic benefits. Freed of the constructed state border barriers, labor would be liberalized to engage in its own decision making and thereby conduct its own cost-benefit analysis and choice of the utility of movement or non-movement to a new employment market.

\section{Consequences of the Omission of Labor Liberalization}

The failure to liberalize labor results in distortive effects in the global market for labor. ${ }^{35}$ While domestic capital producers and consumers are allowed to respond to increased competition originating from outside domestic state borders, labor is prevented from freely and fully responding to the economic stimuli in a productive manner. That is, labor may lose its utility in the then-existing production framework of the domestic economy (i.e., become unemployed or underemployed) because of exposure of domestic producers to trans-border competition in goods, services, capital, and/or ideas. However, labor itself is prevented from competing trans-nationally due to restrictions on trans-border employment opportunities. In addition, and more importantly, the dislocation of labor from overwhelmed domestic producers who decrease their production levels in response to increased competition leads to an oversupply of labor in the domestic economy. Yet, that labor is, in large part, prevented from responding productively to increased trans-border economic opportunities by state constructed and defended borders and barriers to entry. ${ }^{36}$

Nevertheless, the contrast between the economic incentives available in domestic and trans-border markets has resulted and is resulting in the movement of labor responding to those economic stimuli. ${ }^{37}$ Further, the legally enforced immobility of labor and the legally prohibited movement supported by some dominant economic interests lead to exploitation of labor in both home and target economies. The oversupply of labor (increased unemployment or underemployment) in State $A$ drives down or freezes the wages offered to State $A$ 's labor. It is the undocumented and quasi-personhood status of illegally mobile labor in State $B$, and not only the mere presence of

35. DOUGLAS S. MASSEY ET AL., WORLDS IN MOTION: UNDERSTANDING INTERNATIONAL MigRATION AT THE END OF THE MILLENNIUM 14 (1998) ("Border controls reduce the applicability of standard economic models by impeding the free circulation of labour as a factor of production, and, consequently, preventing the development of international migration to its fullest potential.").

36. See, e.g., Caroline Brothers, European Union Passes Measure Allowing Migrants to Be Detained 18 Months, N.Y. TIMES, June 19, 2008, at A6 (discussing the passage of a European Commission Directive mandating stricter standards and requiring the return (deportation) of migrants to their countries of origin).

37. See, e.g., MASSEY, supra note 35, at 277. 
that labor, that facilitates the exploitation of labor in State $B$ and may drive down the wages of domestic labor there. ${ }^{38}$

In addition, the continued assumption and would-be enforcement of labor immobility allows capital to substitute capital and labor trans-nationally and to "price discriminate" in its compensation of labor. Manufacturers and some service providers are able to outsource production to pools of cheap labor held immobile by the national borders of host states. ${ }^{39}$ Service providers whose services must be provided in situ, such as landscapers and roofers, are able to access the cheap labor of the undocumented worker who, due in part to the legal quasi-personhood imposed by the state, accepts lower wages than does the domestic labor force. ${ }^{40}$ That acceptance and willingness on the part of the worker who is illegally present exerts a downward pressure on the wages of some labor providers in the host economy. ${ }^{41}$

\section{PART III-WESTERn HEMISPHERE REgIONAL TRADE AgREEMENTS: LABOR LIBERALIZATION AVOIDED}

As a result of the transnational economic forces it unleashes, trade liberalization constitutes a built-in challenge to state sovereignty and mastery over state territory. ${ }^{42}$ Trade liberalization and globalization are de facto

38. George J. Borjas \& Lawrence F. Katz, The Evolution of the Mexican-Born Workforce in the United States 31-32 (Nat'l Bureau of Econ. Research Working Paper Series, Paper No. 11281, Apr. 2005), available at http://ksghome.harvard.edu/ gboras/Papers/w11281.pdf (discussing the effects of Mexican immigration on the wage levels of unskilled U.S. domestic labor).

39. Manufacturing and certain services (such as reading and interpreting $\mathrm{x}$-rays or paralegal services) are outsourced to India, for example. Further, capital's mobility is not limited only to transnational movement. Production processes and plants may move from one region to another within a domestic market in order to increase transnational and domestic competitiveness. See, e.g., Dan Danielsen, Working Borders: Linking Debates About Insourcing and Outsourcing of Capital and Labor, Roundtable Presentation at the Bernard and Audre Rapoport Center for Human Rights and Justice Conference (Feb. 10-11, 2005), 40 TEX. INT'L L.J. 692, 755-59 (2005); Louis Uchitelle, The Wage that Meant Middle Class, N.Y. TIMES, Apr. 20, 2008, at WK3.

40. See Theresa Hayter, OPEn Borders: The CASE Against IMmigration CONTRols 157 ( $2 \mathrm{~d}$ ed. 2004) (discussing the relationship among illegality of status, ease of exploitation and the extraction of cheap labour).

41. In the United States, for example, the increase in "illegal" immigration stems from the increased dislocation in foreign (Mexican and other) labor markets and economic incentives to undertake transborder movement created by incomplete labor liberalization and globalization coupled with the increased U.S. border security and enforcement.

42. This notion appears to be so obvious as to not require an explicit statement: Through trade liberalization agreements, states limit the flexibility of their legislative and policymaking options with respect to trade. Trade in services, goods, capital, etc., is progressively freed from state control. The proliferation of politically motivated regional trade agreements such as the U.S.-Israel free trade agreement may indicate an unenunciated acknowledgement of the integrative forces unleashed by trade liberalization. The political purpose is to more closely bind 
integrative of economies. Globalization and its engine, trade liberalization, unleash integrative processes despite the best efforts of their wielders to limit the scope of trade liberalization's effects to selected aspects of domestic economies. Confinement of trade liberalization to the movement of goods, capital, services and ideas attempts to deny the inchoate and irrepressible integrative processes in which globalization and trade liberalization are clothed. $^{43}$

However, the benefits anticipated from the liberalization of the movement of goods, services and capital are incomplete where the liberalization of labor is not also undertaken. State participants in regional trading arrangements appear to contemplate undertaking the liberalization of labor only within the context of deliberate/conscious initiatives toward deeper integration of member state economies. In the Western Hemisphere, despite negotiations and agreements to increase the integration of individual economies through regional trading arrangements and the goals of labor liberalization espoused by member states, the plans to liberalize labor are a largely stillborn part of a rhetoric that has not become reality.

\section{A. General Introduction to Regional Trade Agreements}

Regional trading arrangements-the adoption of trade liberalization policies among groups of usually neighboring states-pre-existed the GATT's multilateral trade liberalization endeavor. ${ }^{44}$ Article XXIV of GATT 1947 provided an exception to the GATT's nondiscrimination principles so that preexisting regional trading arrangements did not violate the obligations of the GATT signatories. ${ }^{45}$ As a consequence, regional trading arrangements continued to be formed throughout the pre-Uruguay Round functioning of the GATT, with the number of such arrangements accelerating substantially after $1994 .^{46}$

\section{Espoused Purpose(s) of Regional Trading Arrangements}

The goals of state parties to regional trading arrangements usually include the economic development of domestic economies through the increase in

the member states in the regional trade arrangements to each other. In other words, the integrative effect of economic interdependence is intended to solidify political affinities.

43. The essentially integrative aspects of trade liberalization may have been masked by the long period of stasis (the Cold War) that followed the Bretton Woods process, which, among other things, prevented the formation of the International Trade Organization, which had been envisioned as the institutional embodiment of Bretton Woods-crafted trade liberalization. See Demaret, supra note 18, at 125.

44. See, e.g., Bravo, supra note 9, at 155.

45. GATT 1947, supra note 2, art. XXIV.

46. See Regional Trade Agreements: Facts and Figures, supra note 27. 
trade volumes among member states. ${ }^{47}$ For example, pursuant to CARICOM's Revised Treaty of Chaguaramas, ${ }^{48}$ the objectives of the regional grouping include: "improved standards of living and work[,] full employment of labour and other factors of production[, and] accelerated, coordinated and sustained economic development and convergence....,49 Other underlying factors that contribute to the formation of such arrangements include the geographical proximity of the member states. ${ }^{50}$ Further, pre-existing political, social, cultural or historical ties may strengthen the economic calculus and help overcome some barriers to entering into the arrangements. ${ }^{51}$ These underlying contributing factors are not without economic import; they may confer economic and institution building benefits to the regional trading arrangement. $^{52}$

The classic distinctions among RTAs are the free trade area, the customs union and the common market. ${ }^{53}$ The free trade area is a misnomer. Trade among member states does not become completely free, but it becomes freer than it had been prior to entry into the RTA by virtue of lowering tariff and non-tariff barriers to the movement of goods. ${ }^{54}$ The customs union goes a step further by imposing a common external tariff on goods originating from outside the regional grouping while further lowering the barriers to trade among member states. ${ }^{55}$ The common market is the true free-trade area. Member states remove all barriers to the movement of all factors of

47. The economic development takes place as the increased trade levels stimulate the utilization of Individual domestic factors of production in producing the trade goods and services.

48. See generally CARICOM, Revised Treaty of Chaguaramas Establishing the Caribbean Community including The CARICOM Single Market and Economy, July 5, 2001, available at http://www.caricomlaw.org/doc.php?id=131 [hereinafter Revised Treaty of Chaguaramas].

49. Id. art. 6. See also Agentina-Brazil-Paraguay-Uruguay: Treaty to Establish a Common Market, preamble, Mar. 26, 1991, 30 I.L.M. 1041 [hereinafter Treaty of Asunción]. The Preamble to the Treaty includes in its provisions the objectives of "economic development with social justice" and "the importance of securing . . . a proper place in the international economy." Id.

50. Geographic contiguity may enhance the economic logic of entering into the arrangements. Examples from the Western Hemisphere include NAFTA, which lowers barriers to trade among the contiguous North American states Mexico, Canada and the United States and MERCOSUR, which lowers trade barriers among Brazil, Uruguay, Paraguay, Argentina and contiguous South American states.

51. For example, the majority of the CARICOM member states share a common history. See, e.g., Bravo, supra note 9, at 167.

52. The commonality of interests and experience and a certain level of cultural homogeneity may reduce barriers to the attainment of consensus and decrease the barriers to greater integration. This cultural homogeneity may exist despite the existence of long-term hostilities between contiguous states arising from historic wrongs and competition for resources.

53. Bravo, supra note 9 , at 157.

54. Id.

55. Id. 
production, thus integrating their economies, while maintaining common external tariffs and other barriers to the entry of products and factors of production that originate outside the member states. ${ }^{56}$

That traditional typology is now inadequate. Contemporary regional trading arrangements exhibit a variety of forms that almost defy categorization. Extant examples include the liberalization of barriers with respect to particular economic sectors, agreements between established RTAs and individual countries, ${ }^{57}$ and agreements between two existing RTAs and a neighboring country that is a member of neither RTA. ${ }^{58}$

\section{B. Selected Major Western Hemisphere RTAs}

The Western Hemisphere regional trading arrangements discussed in this $\operatorname{article}^{59}$ vary with respect to, among other things, length of existence, size of

56. Id.

57. The agreement between Mexico and the European Union serves as an example. See generally Economic Partnership, Political Coordination and Cooperation Agreement Between the European Community and its Member States, of the One Part, and the United Mexican States, of the Other Part, Dec. 8, 1997, available at http://www.sice.oas.org/Trade/mex_eu/english/Global_ e.pdf. The European Union and Chile completed a trade agreement in 2002. See generally Association Agreement Between the European Union and Chile, Nov. 18, 2002, available at http://www.sice.oas.org/Trade/chieu_e/cheuin_e.asp.

58. For example, the agreement executed between CARIFORUM (CARICOM plus the Dominican Republic) and the European Union. See Press Release, EU and CARIFORUM Sign Full EPA Agreement (Dec. 16, 2007), available at http://www.delbrb.ec.europa.eu/en/ pres_and_info/releases/Release_Num24-07_EU_CARIFORUM_conclude_EPA_agreement.pdf. The CARIFORUM consensus surrounding the EPA subsequently dissipated, and two of the countries declined to execute the agreement. See Rickey Singh, 13 to Sign EPA: Guyana, Haiti Back Out of Full Agreement, The Jamaica ObSERVER, Sept. 11, 2008. MERCOSUR and the European Union plan to resume negotiations toward the completion of a trade pact between the two regional groupings. See Brazil Sees EU-MERCOSUR Talks Moving Later in 2008, THE GUARDIAN, Apr. 3, 2008, available at http://www.bilaterals.org/article/php3?id_article=11715.

59. Although there are other RTAs in the Western Hemisphere (for a complete list of RTAs in the Western Hemisphere, see, e.g., SICE, http://www.sice.oas.org/agreements_e.asp), CARICOM, MERCOSUR, NAFTA and DR-CAFTA were selected for detailed analysis in this article because of the diversity that these RTAs represent. These include, for example, targeting varying economic goals (such as gradual integration versus market access) and political purposes, common history, disparate global economic importance of member states and of individual RTAs, the similarity and differences of economic development status among member states, and differences in volume of trade. Collectively, CARICOM, MERCOSUR, NAFTA and DRCAFTA represent the array of experiences in the Western Hemisphere, which include diversity of geographic regions and historical experiences, as well as a spectrum of political and economic power in the region and globally. CARICOM, MERCOSUR, NAFTA and DR-CAFTA offer a variety of avenues for analysis-the role of geographic contiguity, historical rivalries and, for the majority of the member states, the transition from being countries of emigration to countries of immigration with a consequent tradition of mobility among their population. In addition, the member states and RTAs discussed here include the two principal legal traditions (civil and 
population and volume of trade affected, as well as with respect to the types and levels of connections among the member states. All four of the RTAs seek to further increase economic activity and trade among member states through successively decreasing the tariff and non-tariff barriers to intra-regional trade in goods. In some cases via amendments, ${ }^{60}$ each of the RTAs also lowers barriers to trade in services and establishes legal regimes to emplace minimum standards for the protection of intellectual property and foreign direct investment. $^{61}$

\section{CARICOM}

CARICOM is a regional grouping primarily composed of former British island colonies in the Caribbean. ${ }^{62}$ Former British colonies Belize and Guyana, located on the Central American and South American mainland, respectively, and former Dutch colony Suriname, are also member states. ${ }^{63}$ CARICOM was created by the 1973 Treaty of Chaguaramas, ${ }^{64}$ and is the smallest and oldest of the RTAs discussed in this article, affecting a population of 14 million. ${ }^{65}$ Key among the goals of this RTA is the creation of a common market and the economic development of the member states. According to the Preamble of the Revised Treaty of Chaguaramas, the objectives of the regional grouping includes "the international competitiveness demanded by the process of globalization ... and the free movement of capital, labor, and technology," among others. ${ }^{66}$ CARICOM's foundational treaty was amended in 1989 to enhance the provisions geared toward the development and implementation of a common market and to bolster the institutional framework of the organization. ${ }^{67}$ In addition, membership was expanded to include Suriname

common law), which leads, with the exception of MERCOSUR, to an admixture of legal traditions within each of the selected RTAs.

60. The MERCOSUR and CARICOM agreements, for example, did not originally include liberalization of trade in services.

61. See, e.g., North American Free Trade Agreement (NAFTA), U.S.-Can.-Mex., Dec. 17, 1992, 32 I.L.M. 289 (1993) [hereinafter NAFTA]. Chapters 11 (Investment Services and Related Matters) and 17 (Intellectual Property).

62. See Bravo, supra note 9 , at 167-76 (providing description and analysis of the historical background of the CARICOM regional grouping).

63. The fifteen member states are Antigua and Barbuda, The Bahamas, Barbados, Belize, Dominica, Grenada, Guyana, Haiti, Jamaica, Montserrat, St. Lucia, St. Kitts and Nevis, St. Vincent and the Grenadines, Suriname, and Trinidad and Tobago.

64. Barbados-Guyana-Jamaica-Trinidad and Tobago: Treaty Establishing the Caribbean Community, July 4, 1973, 12 I.L.M. 1033.

65. Bravo, supra note 9 , at 168.

66. Id. at 171.

67. See The CARICOM System: BasiC InStRuments 459-69 (Duke Pollard ed. 2003) (discussing the impetus for and changes wrought by the Revised Treaty). 
and Haiti. ${ }^{68}$ However, a key centerpiece of the Revised Treaty, the Caribbean Single Market and Economy (CSME), was not implemented until 2005. ${ }^{69}$

\section{MERCOSUR}

The 1991 Treaty of Asunción executed by Brazil, Argentina, Paraguay and Uruguay created the Common Market of the Southern Cone (MERCOSUR) and became effective on December $31,1994 .^{70}$ Chile and Bolivia joined the grouping as Associate Members in $1996,{ }^{71}$ as did Peru in 2005. ${ }^{72}$ MERCOSUR is the second largest of the RTAs discussed in this essay and the second largest in the Western Hemisphere. ${ }^{73}$ According to the Treaty of Asunción, the ultimate goal of MERCOSUR is South American economic integration, ${ }^{74}$ and the immediate purpose of the Treaty is the formation of a common market and integration of member state economies. ${ }^{75}$ Some aspects of the rationales for the formation of MERCOSUR appeared to mirror the reasoning underlying the formation of the European Communities. ${ }^{76}$

68. Haiti's membership has been largely defunct since the overthrow of President Bertrand Aristide in 2004. Bravo, supra note 9, at 203 n.280.

69. See id. at 173-75 (discussing obstacles to Caribbean integration, which include hurdles to the implementation of the CSME).

70. Treaty of Asunción, supra note 49, art. 1. The December 17, 1994, Supplementary Protocol to the Asuncion Agreement on the Institutional Structure of the MERCOSUR (the Protocol of Ouro Preto) lays out the institutional structures and mechanisms for implementation of the common market.

71. See Rafael A. Porrata-Doria, JR., MERCOSUR: The COMmon Market of the SOUTHERN CONE 123-24 (2005).

72. See Acuerdo de Complementacion Economica Suscrito Entre los Gobiernos de la Republica Argentina, de la Republic Federative del Brasil, de la Republica del Paraguay y de la Republica Oriental del Uruguay, Estados Partes del MERCOSUR, y el Gobiemo de la Republica del Peru, Nov. 30, 2005, available at http://www.sice.oas.org/trade/MRCSRPerACE58/ace.asp.

73. NAFTA is the largest RTA in terms of volume of trade and, due to the status of the United States in the Western Hemisphere, is probably the most significant in the political sphere.

74. The Preamble states: "[T]his Treaty must be viewed as a further step in efforts gradually to bring about Latin American integration," and speaks of "increasingly close ties between [the] peoples" of the member states. Treaty of Asunción, supra note 49.

75. Article 1 states: "The States Parties hereby decide to establish a common market, which shall be in place by 31 December 1994 and shall be called the 'common market of the southern cone' (MERCOSUR)." Among the mechanisms that will be included in the formation of the common market are " $[\mathrm{t}]$ he free movement of goods, services and factors of production between countries...." Treaty of Asunción, supra note 49 (emphasis added).

76. See PORRATA-DORIA, supra note 71, at 17-21 (discussing similarities between the Brazil-Argentina and the France-Germany relationships, such as historic enmities and the similarity in economic relationships between the two states). 


\section{NAFTA}

In 1994, the United States, Mexico and Canada executed NAFTA, ${ }^{77}$ creating the largest regional grouping in the Western Hemisphere in terms of volume of trade and size of the population of the member states. The purpose of the establishment of the free trade area was to eliminate trade barriers among the member states, promote fair competition, increase investment opportunities and protect intellectual property rights. ${ }^{78}$ The goals expressed in contemporaneous statements by the leaders of the three member states included, among other things, increasing trade among the member states in order to spur economic growth and increase member state prosperity. ${ }^{79}$ The NAFTA was extremely controversial in U.S. domestic politics and continues to evoke strong negative views and rhetoric from some politicians and a number of civil society groups. ${ }^{80}$

\section{DR-CAFTA}

The Dominican Republic-Central American Free Trade Area Agreement, executed on August 5, 2004, among the United States, the Dominican Republic and several Central American countries, ${ }^{81}$ replicates many of the provisions and characteristics of NAFTA. ${ }^{82}$ As is the case with NAFTA, a key goal of DR-CAFTA is to foster economic development and economic activity by

77. NAFTA, supra note 61 .

78. See id. art. 102.

79. See, e.g., Ranko Shiraki Oliver, In the Twelve Years of NAFTA, The Treaty Gave to Me... What, Exactly?: An Assessment of Economic, Social, and Political Developments in Mexico Since 1994 and Their Impact on Mexican Immigration into the United States, 10 HARV. LATINO L. REV. 53, 62-65 (2007) (discussing the economic benefits that the NAFTA parties sought from the trade pact).

80. See, e.g., Peter T. Kilborn, Unions Gird for War Over Trade Pact, N.Y. TIMES, Oct. 4, 1993, at A14 (discussing organized labor's concerns about NAFTA); David E. Rosenbaum, Splintered on Trade; 2 Unusual Political Alliances Reflect Long-Term Gain and Short-Term Fear, N.Y. TIMES, Sept. 15, 1993, at B12 (summarizing arguments for and against U.S. entry into the free trade agreement). See also Roger Lowenstein, Tariff to Nowhere, N.Y. TIMES, June 15, 2008, at 15 (discussing the anti-trade liberalization rhetoric of Barack Obama and Hillary Clinton the 2008 Democratic candidates for President of the United States).

81. The Central American member states are Costa Rica, El Salvador, Guatemala, Honduras and Nicaragua. Dominican Republic-Central America-United States Free Trade Agreement, May 28, 2004, 43 I.L.M. 514, available at http://www.ustr.gov/Trade_Agreements/Regional/CAFTA/ DR-CAFTA_Final_Texts/Section_Index.html [hereinafter DR-CAFTA].

82. DR-CAFTA is one of a series of free trade agreements that the United States has executed or negotiated since the 1994 NAFTA became effective. In each of the subsequent agreements, the United States has been the initiator of the arrangement and has brought to the table a template of demands that it successively revised to further enhance its trading position within the specific regional grouping. See Cherie O. Taylor, Regionalism: The Second-Best Option?, 28 ST. LOUIS PUB. L. REV. 155 (2008). 
increasing trade among the member states. Although the agreement encountered some resistance among the polity in at least one of the member states, ${ }^{83}$ through successive signatures and ratifications the RTA is now in force. $^{84}$

The analysis of the four RTAs identifies a gap between both the purposes of and the rhetoric employed by, on the one hand, the CARICOM and MERCOSUR parties, and the NAFTA and DR-CAFTA parties on the other. That gap stems from the economic integration and common market formation goals espoused by CARICOM and MERCOSUR, which contrast with the more superficial relationships sought by the NAFTA and DR-CAFTA parties. ${ }^{85}$ For the latter pair of regional trade arrangements, labor liberalization is addressed only indirectly as part of the liberalization of trade in services.

\section{Overview of Treatment of Labor Liberalization under the Four Western Hemisphere RTAs}

The treatment of labor liberalization in the four referenced regional trading arrangements in the hemisphere falls into two categories. In one category are CARICOM and MERCOSUR, pursuant to which the member states claim to aspire to a fundamental integration of their economies by creating a common market. ${ }^{86}$ In the second category are NAFTA and DR-CAFTA, both of which attempt to capture the preferential market access benefits of regional trade liberalization while holding at bay the human aspect of the inevitable process of integration of member state economies.

\section{CARICOM}

In keeping with CARICOM's goal of a common market, the Preamble to the Revised Treaty of Chaguaramas sets forth the objective of the free

83. See Costa Rica: Trade Pact Appears to Pass, N.Y. TimES, Oct. 9, 2007, at A6; U.S. Trade Pact is Protested in Costa Rica, N.Y. TimES, Oct. 1, 2007, at A11.

84. However, the DR-CAFTA treaty has not yet been implemented in Costa Rica. See Costa Rica: Delay in Trade Agreement Sought, N.Y. TIMES, Jan. 30, 2008, at C5.

85. However, CARICOM and MERCOSUR also can be distinguished by the inner-directed and outer-directed fear of the hegemon. The member states of MERCOSUR fear both the wouldbe/perceived South American hegemon within, Brazil, as well as the Western Hemisphere's acknowledged hegemon, the United States. The CARICOM member states, on the other hand, include no state with the potential to become a regional hegemon. The member states' fears of domination are outwardly directed toward the United States. In light of these realities, and dependent upon whether the RTAs decide to be active or reactive, economic integration, which includes sanctioning of labor liberalization, may take place only as a reaction to the activities of the United States.

86. See supra Parts III.B.1 and III.B.2. 
movement of community nationals. ${ }^{87}$ However, to date, commitments to labor liberalization have been limited to a small subset of CARICOM nationals. ${ }^{88}$ Movement is restricted to certain categories of labor, such as professionals, skilled artists and sports figures. ${ }^{89}$ An additional provision, an establishment clause, liberalizes movement of community nationals and legal entities for purposes of establishing a business entity in another CARICOM member state. ${ }^{90}$ Despite the limited implementation of the goal of free movement of community nationals (and, therefore, of labor liberalization) and in spite of existing state barriers, anecdotal evidence suggests the reality of substantial intra-regional labor movement among CARICOM states and between CARICOM states and other states and regions. ${ }^{91}$

\section{MERCOSUR}

The Treaty of Asunción enumerates as one of its goals the liberalization of all factors of production ${ }^{92}$ and the creation of a single market. ${ }^{93}$ Nevertheless,

87. The Preamble of the Revised Treaty of Chaguaramas speaks of member state awareness "that optimal production by economic enterprises in the Community requires the structured integration of production in the Region, and particularly, the unrestricted movement of capital, labour and technology." Revised Treaty of Chaguaramas, supra note 48 (emphasis added).

88. While, in Article 45, the member states commit themselves "to the goal of free movement of their nationals within the Community," Article 46 limits the scope of that seeming liberalization. Id. arts. 45-46.

89. The Revised Treaty of Chaguaramas accords the right to seek employment in the jurisdiction of member states to "(a) University graduates; (b) media workers; (c) sportspersons; (d) artistes; and (e) musicians, recognised as such by the competent authorities of the receiving Member States." Id. at art. 46. The legal tradition of the member states requires that treaty commitments must first be transposed into domestic law in order to become effective. Bravo, supra note 9 , at $192-94$.

90. Revised Treaty of Chaguaramas, supra note 48, arts. 30-34 (prohibiting the imposition of new barriers to the right of establishment of the nationals or domestic legal entities of another member state). The establishment clause may be viewed as a capital liberalization mechanism rather than one of labor liberalization.

91. For example, there is significant economic migration from Jamaica, a CARICOM member state, to the Dutch territories in the Caribbean, such as St. Martin and Aruba, and to the United States. Because of the paucity of CARICOM-generated statistical information on intraregional movement, this statement is based on anecdotal sources, such a newspaper reports and the author's own observations. St. Martin Moves on Immigration Problem, JaMAICA GLEANER, Jan. 25, 2007, available at http://www.jamaica-gleaner.com/gleaner/20070125/news/new66.html (discussing St. Martin initiative to limit illegal migration with efforts directed at Jamaica, Dominica, Guyana and Suriname). Jamaica itself is a destination for labor from other states.' See, e.g., Haitian Dancers Fire Up North-Coast Clubs, JAMAICA GLEANER, July 6, 2008, available at http://www.jamaica-gleaner.com/gleaner/0080706/lead/lead3.html (discussing the smuggling of Haitian women to work as dancers in Jamaican clubs).

92. Chapter 1, article 1 provides in pertinent part that the "common market shall involve: The free movement of goods, services and factors of production ..." Treaty of Asunción, supra note 49 , ch. 1 , art. 1 (emphasis added). 
like CARICOM (and perhaps even more so than CARICOM), labor has not been liberalized by the regional grouping. The rhetoric of the single or common market is undercut by the lack of adoption or implementation of provisions that would allow labor to respond to the economic incentives and forces created by the liberalization of other aspects of the constituent domestic economies of member states. Instead, MERCOSUR has followed the cosmetic course of appearing to increase or shore up the substantive protection of labor standards, ${ }^{94}$ while largely ignoring the pressure to liberalize labor as one of the classic factors of production. Despite this apparent foot dragging, the creation of the Sociolaboral Commission and other efforts at standard setting with respect to the rights and treatment of migrant workers may imply member states' tacit acknowledgment of the reality of substantial intra-regional movement of labor-a reality that is in tension with member states' reluctance to undertake obligations to officially open their borders to host such labor.

\section{NAFTA}

An underlying, if un-enunciated, goal of NAFTA was the immobilization of Mexican labor - the desire and intent that Mexicans would, through the operation of NAFTA, have a greater economic incentive to remain behind the Mexico-United States border, thus breaking (or, at the very least, significantly decreasing) the cycle of seasonal trans-border movement to the United States. ${ }^{95}$ With respect to labor, the purpose of NAFTA is to impose labor immobility through economic development, not to liberalize labor. The expectations of the governments of the NAFTA member states were that higher levels of foreign direct investment and consequent job creation in Mexico, together with upward equalization of wages, would stem immigration of low-skilled labor to the United States. ${ }^{96}$ As a result, NAFTA does not provide for the liberalization

93. Chapter 1, article 1 states: "The States Parties hereby decide to establish a common market, which ... shall be called the "common market of the southern cone' (MERCOSUR)." Id. ch. I, art. 1.

94. In 1998, through the adoption of the Sociolaboral Declaration, MERCOSUR created the Comision Sociolaboral del MERCOSUR, whose purpose is to provide a policymaking and factfinding forum related to regional labor standards. See Creación de la Comisión Socio Laboral del MERCOSUR [Creation of the Sociolaboral Commission of MERCOSUR], Dec. 10, 1998, MERCOSUR/GMC/Res. $\mathrm{N}^{\circ} 15 / 99$, English translation available at http://www.unionnetwork.org/unigraphical.nsf/527af848b17f3b51c125689b00418df6/66b31628f43d043ac12570b9 00305043/\$FILE/EN-Declaraci\%C3\%B3n\%20Sociolaboral\%20del\%20MERCOSUR.doc.

95. See, e.g., STEPHEN CASTLes \& MARK J. Miller, The AgE Of MigRation 119 (3d ed., The Guilford Press 2003) (1993) (asserting that "[t]he persistence of illegal migration to the USA ... was taken by many as proof that a new strategy of 'abatement' was needed to replace or complement a strategy of deterrence. Such considerations played a major part in the discussions which led up to NAFTA in 1993").

96. See, e.g., Oliver, supra note 79 , at 62-63 (discussing hopes that economic stability in Mexico would decrease the number of Mexican immigrants to the United States). 
of labor and allows for the movement of skilled labor only. ${ }^{97}$ For example, through the introduction of the Trade NAFTA (TN) visa in the United States, which includes an application process that may be more stringent and arduous for Mexican applicants, skilled labor from Mexico and Canada may seek temporary trans-border employment in the United States. ${ }^{98}$ However, NAFTA does not create unfettered rights of nationals of member states to enter the labor market of another member state. ${ }^{99}$

\section{DR-CAFTA}

In DR-CAFTA, the United States turned its back on the narrow opening to the liberalization of labor represented by the TN visas. The provisions of DRCAFTA, which reflect the snowballing increase in anti-immigrant sentiments in the United States, are even more hostile to the liberalization of labor than is NAFTA. The TN visa provisions of NAFTA are omitted from DR-CAFTA, and DR-CAFTA neither creates an analogous visa category nor expands upon the NAFTA skilled labor visa category that allows the temporary movement of skilled labor. At the same time, DR-CAFTA replicates the provisions of NAFTA that specifically withhold the prospect of rights of member state nationals to access another member state's labor market. ${ }^{100}$ However, like

97. See Ryszard Cholewinski, International Labour Law and the Protection of Migrant Workers: Revitalizing the Agenda in the Era of Globalization, in GLOBALIZATION AND THE FUTURE OF LABOR LAW 409, 434 n.3 (John D.R. Craig \& S. Michael Lynk, eds. 2006) ("[G]eneral free movement of labour is not a feature of [NAFTA] . . . This agreement only facilitates the entry of specified skilled professionals and business persons into these countries." (citation omitted)).

98. See NAFTA, supra note 61 , ch. 16, arts. 1601-1608 and annex 1603 (providing for the temporary entry of business visitors, traders and investors, intra-company transferees and professionals). See also Oliver, supra note 79, at 125-27 (describing the process of application for TN visas and contrasting their use by Mexican and Canadian nationals from 1999-2005). Ironically, the post-adoption period has seen limited use of the TN visa by skilled Mexican labor simultaneously with a vast expansion in the trans-border movement of unskilled Mexican labor. Id. at $117-18,125-30$.

99. Article 1607 of NAFTA carefully enumerates (and limits) the provisions that affect the immigration laws of the NAFTA and states: "Except for [specified chapters], no provision of this Agreement shall impose any obligation on a Party regarding its immigration measures." NAFTA, supra note 61 , art. 1607.

100. The language of both NAFTA and DR-CAFTA echo the language of the GATS, which makes clear that the liberalization of trade in services and the consequent removal of barriers to the movement of some agents of service providers do not create rights to access the labor markets of member states. See NAFTA, supra note 61 , ch. 12, art. $1201 \S 3$, which provides in pertinent part that:

Nothing in this Chapter shall be construed to ... impose any obligation on a Party with respect to a national of another Party seeking access to its employment market, or employed on a permanent basis in its territory, or to confer any right on that national with respect to that access or employment.... 
NAFTA, DR-CAFTA conveys the superficial impression that it requires the maintenance of existing labor standards within member states and that it prohibits efforts to lower such standards in response to the liberalization of trade among the member states. ${ }^{101}$ However, those protections appear to be illusory. ${ }^{102}$

\section{Analysis of Treatment of Labor under the Four Western Hemisphere RTAs}

Contemporary RTAs in the Western Hemisphere address the issue of labor through the use of three principal mechanisms. The first mechanism is a manifestation of linkage concerns-in this case, "trade and . . labor."103 It consists of the introduction of provisions in the RTA or connected to the RTA that appear to offer the maintenance and enforcement of existing domestic law labor standards by member states after entry into force of the RTA. ${ }^{104}$ The provisions appear to be aimed at the protection of labor standards within and by member states that might otherwise not have the capacity to withstand

Similarly, DR-CAFTA states: "This Chapter does not impose any obligation on a Party with respect to a national of another Party seeking access to its employment market." DR-CAFTA, supra note 81 , art. $11.1 \S 5$.

101. In DR-CAFTA, the trade and labor linkage concerns are addressed in the body of the agreement. See DR-CAFTA, supra note 81, ch. 16. Contrast this with the North American Agreement on Labor Cooperation, which was negotiated and drafted in response to U.S. domestic labor union animosity to the NAFTA trade pact. North American Agreement of Labor Cooperation, U.S.-Can.-Mex., Sept. 14, 1993, 32 I.L.M. 1499 (1993) [hereinafter NAALC]. See, e.g., Adam Brower, Note, Rethinking NAFTA's NAALC Provision: The Effectiveness of its Dispute Resolution System on the Protection of Mexican Migrant Workers in the United States, 18 IND. INT'L \& COMP. L. REV. 153, 155-57 (2008) (discussing the purposes and timeline of the NAALC).

102. The NAALC has provided little restraint against the lowering of labor standards within the domestic law of the NAFTA parties, and there is little prospect that the labor provisions of DR-CAFTA will have greater protective effect on the labor standards of parties to that agreement. See infra Part V.A.2.

103. See, e.g., NAALC, supra note 101, at 1502 (indicating that the Preamble recites the importance of labor issues in the furtherance of NAFTA's trade policies).

104. Examples of such instruments include the NAALC (affirming NAFTA member states' obligations to adhere to their domestic labor standards and providing for an oversight/review institution); the Sociolaboral Declaration of the MERCOSUR (proclaiming the support of MERCOSUR and individual member states for the International Labor Organization (ILO) Declaration of Fundamental Principles and Rights at Work, as well as other pertinent international labor and human rights instruments); and the CARICOM's Charter of Civil Society and Labor Law Harmonization Project (whereby a panoply of workers rights are acknowledged and attempts are made to set and harmonize labor laws of the member states). For excellent discussions and analysis of the substantive labor law instruments and initiatives of these RTAs, see Adelle Blackett, Toward Social Regionalism in the Americas, 23 COMP. LAB. L. \& POL'Y J. 901 (2002) and Lance Compa, Labour Rights in the FTAA, in GLOBALIZATION AND THE FUTURE OF LABOR LAW, supra note 97, at 245. 
downward pressures on those standards. ${ }^{105}$ However, in the case of NAFTA (and perhaps of DR-CAFTA as well), the provisions' purpose was to protect the jobs of workers in the more highly compensated labor markets of more powerful member states through elimination of a potential incentive for the trans-border movement of capital that might be tempted to access the lower cost trans-border labor market. ${ }^{106}$ The would-be protectionist aims are evidenced by subsequent lackluster impact of these provisions on NAFTA parties and the ineffectiveness of deploying the provisions to maintain and enforce labor standards. ${ }^{107}$

A second mechanism consists of provisions aimed at the liberalization of trade in services. Here, trade in services is liberalized and the free movement of capital (foreign direct investment) is enhanced by allowing the limited movement of human agents of service providers. ${ }^{108}$

A third mechanism employed is the enumeration of specific categories of labor providers that may move freely among member states. Some examples

105. See, e.g., Blackett, supra note 104, at $940-41$ (noting that,"as individual micro-States, which face trade liberalization and the need to compete to attract foreign investment, Caribbean nations need mechanisms to address sensitive policy issues in a collective manner to avoid undesirable forms of competition").

106. While this purpose is not stated in the NAALC, it is a logical reading of the events giving rise to the negotiation and execution of the agreement and of the rhetoric employed by the NAFTA parties' heads of state. See, e.g., Noemi Gal-Or, Labor Mobility Under NAFTA: Regulatory Policy Spearheading the Social Supplement to the International Trade Regime, 15 ARIZ. J. INT'L \& COMP. L. 365, 384 (1998).

The NAALC was proposed as a condition for congressional ratification of the controversial NAFTA, and was designed to limit illegal migration between the United

States and Mexico, and the luring of jobs and investments away from any of the Parties.

It does not, however, address the issue of labor mobility at all. Moreover, it does not even address labor standards.

Id. (citations omitted).

107. See, e.g., Christine Kaufmann, Globalization and Labour Rights: The CONFLICT BETWEEN CORE LABOUR RIGHTS AND INTERNATIONAL ECONOMIC LAW 191-92 (2007) (discussing inherent weaknesses and inadequate use of NAALC procedures). But see Blackett, supra note 104, at 930 (discussing the NAALC institutions' facilitation of greater transparency and input by civil society actors, while acknowledging negative perceptions of the NAALC institutional framework).

108. These provisions mimic Mode 4 of the GATS as set forth in the GATS, supra note 28. The GATS' conceptualization of trade in services is echoed in the four RTAs discussed in this Article. See NAFTA, supra note 61, art. 1201; Revised Treaty of Chaguaramas, supra note 48 art. $36 \S 4$; Montevideo Protocol on Trade in Services of Mercosur, Part II (Protocolo de Montevideo sobre el Comercio de Servicios del Mercosur), approved my MERCOSUR Decision 13/97 (Dec. 15, 1997), entered into force Dec. 7, 2005; DR-CAFTA, supra note 81, art. 11 \$ 14. 
of those categories include, among others, university graduates, skilled workers, artists and sports figures. ${ }^{109}$

An additional category of trade liberalization provisions that may tangentially impact the liberalization of labor is an establishment clause, which permits the trans-border movement of member state nationals for the purpose of establishing entrepreneurial business ventures. ${ }^{110}$

Analysis of the RTAs' provisions and implementation reveals a second gap: ${ }^{11}$ that between the rhetoric employed within the CARICOM and MERCOSUR regional trading arrangements and the implementation actually effected within them. Both CARICOM and MERCOSUR's espoused primary purpose is to create a common market, and both of these RTAs have established a common external tariff. However, although both have discussed, alluded to and, in the case of CARICOM, provided in constitutive instruments for, labor liberalization as part of the creation of that common market, the implementation of these provisions has been much slower than has been the implementation of the elimination of barriers to, for example, the movement of goods or capital.

On the other hand, NAFTA's and DR-CAFTA's treatment of labor functions as an express denial of the integration process, in defiance of the inescapably integrative processes stimulated by trade liberalization. NAFTA's purpose with respect to labor and its mobility was and continues to be the reverse of labor liberalization. ${ }^{112}$ The member states' expectation was that labor would be frozen in place through the economic forces created by the liberalization of capital and goods. That plan proved fruitless and, indeed, was a direct result of policy makers and negotiators ignoring the pre-existing, deep trans-border labor market links between Mexico and the United States. ${ }^{113}$

\section{PART IV - BARRIERS TO LABOR LIBERALIZATION}

The reasons for the neglect of labor liberalization within regional trading arrangements are similar to those that underlie the neglect on the multilateral level. The barriers to the liberalization of labor are conceptual, economic, social, psychological and political.

109. See, e.g., Revised Treaty of Chaguaramas, supra note 48, art. 46. See Gabriel Gari, Legal Instruments for the Liberalization of Trade in Services at the Sub-Regional Level: The Mercosur Case, 25 PENN. ST. INTL L. REv. 659 (2007) (discussing and analyzing the MERCOSUR trade in services regime).

110. See, e.g., id. art. 32.

11. See supra Part MI.B.4 (discussing the first gap).

112. See supra Part III.C.3-4 (discussing NAFTA's labor immobilization purpose).

113. See generally Bill Ong Hing, Immigration Policy: Thinking Outside the (Big) Box, 39 CONN. L. REV. 1401, 1410-29 (2007) (discussing the deep and extensive historic links between the United States' and Mexico's labor markets). 


\section{A. Conceptual Barriers}

Fundamental conceptual understandings underlie the neglect (and even rejection) of labor liberalization. Linked to those conceptual understandings is a fear of change. The first and most far-reaching of those conceptual understandings is an unquestioning assumption of the trans-border immobility of labor. That conceptualization coexists uneasily with the deployment of state immigration and national security laws aimed at thwarting the movement of labor. ${ }^{114}$

The second conceptual barrier is the vastly influential unarticulated conception of capital or goods as neutral, especially as contrasted with labor. This is incorrect. The introduction of a new product or good may transform the culture and economy of a given society. For example, the owners of capital may demand concessions and changes from the leadership and population of State $A$, which may lead to transformation of the culture. ${ }^{115}$ Those transformations span the gamut of social, cultural, economic and political spheres. ${ }^{116}$ The effects of capital infusions and introduction of new goods may be no more subject to easy state control than is labor, in either its individual or group forms. ${ }^{17}$

A third conceptual cause of the neglect of labor is the (perhaps willful) lack of understanding of policymakers and politicians that trade liberalization

114. See, e.g., CASTLES \& MILlER, supra note 95, at 117-20. This conceptualization continues to exist in economic and other policymaking models despite the massive migratory flows of the twentieth century. Id. at 68-92.

115. Think of the influence of bilateral investment treaties (BITs). For example, the BITs executed by the United States with other countries typically include, inter alia, minimum standards for the treatment of U.S. investors under the domestic law of the host countries, nondiscrimination (both national treatment and most favored nation) provisions, prohibitions of constraints on the export of capital, and prohibitions of performance guarantees. See, e.g., PRACTISING LAW INSTITUTE, United States Model Bilateral Investment Treaty, in Litigation 2006, arts. 3, 5, 7, 8 (PLI Litig. \& Admin. Practice, Course Handbook Series No. 8710, 2006). For discussion and analysis of the spread of BITs and of their effects on less-developed countries, see Zachary Elkins et al., Competing for Capital: The Diffusion of Bilateral Investment Treaties, 1960-2000, 2008 U. ILL. L. REV. 265, 265-303 (2008). See also Andrew T. Guzman, Why LDCs Sign Treaties that Hurt Them: Explaining the Popularity of Bilateral Investment Treaties, 38 VA. J. INT'L L. 639, 639-88 (1998).

116. A quintessential example is the introduction of tea to England in the seventeenth century by Catherine of Braganza. See United Kingdom Tea Council, www.tea.co.uk/indes.php?pgId=96 (last visited Oct. 10, 2008). Tea is now an integral part of English culture.

117. It is true, however, that at the extreme, capital is also restricted in its trans-border movement. The U.S. reaction to proposed control of U.S. ports by UAE investors provides an example. See, e.g., David S. Cloud, Port Deal's Collapse Stirs Fears of Repercussions in Mideast Ties, N.Y. TIMES, Mar. 11, 2006, at A10; Heather Timmons, Dubai Port Company Sells Its U.S. Holdings to A.I.G., N.Y. TIMES, Dec. 12, 2006, at C4. Such measures are usually due to nationalist and state security concerns discussed later in this article. See infra Parts IV.D-E. 
is inherently integrative, fostering the interdependence of individual economies and societies. The attempts to limit integration so as to constrain labor's responsiveness to economic incentives creates distortive effects in individual domestic economies, as well as opportunities for exploitation within the global market for labor.

A fourth potential conceptual barrier is a misunderstanding and fear of the consequences of the liberalization of labor. The labor liberalization advocated here would not serve to commoditize labor so as to facilitate labor's increased exploitation by others, but to free labor of constraints that now prevent it from seeking the most competitive compensation levels. ${ }^{118}$ The liberalization of labor would serve the human rights of individual labor providers, not sacrifice those rights for the economic purposes of others.

A fifth conceptual barrier that underlies the neglect of labor liberalization is the non-holistic conceptualization of humans as economic actors. It is difficult to conduct holistic economic analysis that conveys a complete analysis of human beings as economic actors-both producers and consumers, as well as actors and re-actors in creating and responding to economic forceswho at the same time possess the status of bearers of fundamental rights under international and domestic law. Humans are intrinsically economic actors in the roles of both producers and consumers. However, in their role as "labor" they are often analyzed and conceived of as inherently immobile and belonging to a particular state.

Sixth, political concepts such as statehood and sovereignty, and the consequent protectionism, also have an impact. ${ }^{119}$ They underlie the contemporary model of trade liberalization, which functions as an instrument of power politics instead of as a mechanism for enhancing welfare for all economic participants. From the political division into nation-states arises the dominant atomized nation-state world view, as opposed to a universalized and globalized perspective. The atomized view of the world results in the gap between the rhetoric and language of globalization and the domestic nationstate interests that are pursued by policy makers and politicians. ${ }^{120}$

Finally, the psychological mechanisms that allow humans to adjust and continue to function in the face of apparent injustice and random sufferingthe human belief in the fundamental justice of the human condition, that

118. See supra Part II.C.

119. See infra Part IV.E.

120. Also worthy of further exploration is the question whether the influence of the U.S.dominated emphasis on civil and political human rights, as opposed to economic, social, and cultural rights, underlies the failure to fully conceptualize and facilitate the economic role and functioning of individuals as autonomous economic units in a globalizing world. 
individuals get what they deserve-plays a key role. ${ }^{121}$ The belief in a just world allows the more privileged onlooker to blame the victim and to maintain continued belief in the essential justice and ordering of human and societal interactions. ${ }^{122}$ If undocumented migrants are exploited, they are to blame for their condition, so that the structural causes and the injustice of barriers to their access to worthwhile employment conditions are not widely or fundamentally questioned.

\section{B. Psychological Barriers}

The psychological barriers to labor liberalization as an inherent part of trade liberalization are based on a fear of the "Other," cultural protectionism and a deeper underlying fear of change. Nation-states and their citizens rely on a mythos of homogeneity, and human psychology naturally distinguishes between "us" and "them," the in-group and the out-group. ${ }^{123}$ Labor liberalization appears to be unthinkable because fear of the Other requires that the Other be held at bay and prevented from entering the body politic. That entry, it is feared, will bring to the host society both danger from the stranger within as well as change.

However, change, including cultural transformation, is inevitable and comes subtly and inevitably will-they or nil-they to both isolationist and open societies. The flexible, open and transparent society may be able to welcome change on its own terms and direct the path of its flow. By utilizing a longterm time horizon, it is possible to appreciate the benefits of openness and the ability to harness change. For example, in the United States, the historically dominant practice of welcoming immigrants brought the transformation of waves of the "Other" into "Americans;" the society was transformed (as it inevitably would have been), and positive economic benefits were realized. ${ }^{124}$ The dynamism, richness, strength and power of the United States experience would have been impossible had the borders of the United States been closed to the Others who both voluntarily entered in search of economic opportunity and were involuntarily consigned to enslavement to the economic benefit of others. ${ }^{125}$ Yet each wave of Americanized Others attempts to pull up the

121. See Melvin J. LeRner, THE Belief in A JuSt WORLD: A Fundamental Delusion 11-13 (1980).

122. Id. at 89-103 (discussing, among other things, "disidentifying" by the powerless and "the importance of 'deservingness" to the norm of social responsibility).

123. See, e.g., JohanNEs Fabian, TIME AND THE OTHER: How ANTHROPOlOGY MAKES ITS OBJECT X-xi (1983); ERIC WOLF, EUROPE AND THE PEOPLE WITHOUT HISTORY 354-55 (1982).

124. See, e.g., Felix S. Cohen, The Social and Economic Consequences of Exclusionary Immigration Laws, 2 NAT'L L. GuILD Q. 171, 172-74 (1940).

125. The article's acknowledgement of the role of trans-Atlantic slavery in supplying the U.S. domestic labor market conveys no normative support for the exploitation. 
ladder behind it, fearful of new Others and their potentially transformative effects. ${ }^{126}$

\section{Social Barriers}

The psychological barriers (fear of the Other, fear of cultural transformation and change) are intimately intertwined with the social causes of the failure to address labor liberalization. Fundamentally, the fear of the Other underlies the floodgates argument - the notion that, if the barriers to entry are liberalized through trade, the domestic life, culture, economy and polity will be swamped by a flood of foreign-sourced Other labor. ${ }^{127}$

Intrinsic in this fear is the apprehension that the Other cannot be assimilated and that the native will be dislocated and outnumbered. This fear is enhanced by the use of a historically short and blinkered time horizon. The previously mentioned example of the United States as a long-term beneficiary of foreign-sourced trans-border labor is a key example that undermines the power of this threatening image. ${ }^{128}$

Further, the historical evidence suggests that the flows of labor are selfcorrecting. The vast majority of Italians and Swedes did remain in Italy and Sweden during the height of Italian and Swedish migration to the New World. ${ }^{129}$ There are built-in checks to the prospect of floods of new labor overwhelming the infrastructure and people of a given state. Firstly, information asymmetries are not as stark as they were during the previous eras of economically driven world migration. ${ }^{130}$ Would-be economic migrants (labor attempting to sell its services to the most profitable bidder) are better able to gauge the existence or non-existence of opportunities for employment in a given location. The flow of responsive labor will rise and fall in response

126. See, e.g., Felix S. Cohen, The Mythology of Immigration, in THE LEGAL CONSCIENCE: SELECTED PAPERS OF FELIX S. COHEN 384-89 (Lucy Kramer Cohen ed. 1960).

127. See, e.g., KEVIN R. JOHNSON, OPENING THE FlOODGATES: WHY AMERICA NEEDS TO RETHINK ITS BORDERS AND IMMIGRATION LAWS 26-27 (2007).

128. See, e.g., George J. Borjas, The Economics of Immigration, $32 \mathrm{~J}$. OF ECON. LITERATURE 1667,1713 (1994) (The author concluded that "there was little evidence to suggest that immigrants had an adverse impact on native employment opportunities. Overall, the empirical evidence painted a very optimistic picture of the contributions of immigrants to the American economy.").

129. The same is true of the Irish, even in the throes of the Potato Famine. Other illustrative contemporary examples include the movement between, for example, the U.S. mainland and Puerto Rico or among the states of the United States. JOHNSON, supra note 127, at 28-29. That is, despite the many advantages that California enjoys, not all U.S. residents have or will relocate there from other states.

130. See, e.g., Sara Corbett, Can the Cellphone Help End Global Poverty?, N.Y. TIMES MAGAZINE, Apr. 13, 2008, at 35 (discussing the economic benefits of the enhanced access to information through cell phones). See also Tom Arango, Market Data, Far From the Market, THE N.Y. TIMES, June 29, 2008, at BU4. 
to the economic stimuli of individual labor markets. Secondly, for a number of reasons, including fear of the new and of the difficulties of adjustment to a new society and culture and diminished social status as the Other, many individual purveyors of labor will not wish to leave familiar social and cultural circumstances. Thirdly, as excess (unemployed or underemployed) labor leaves State $A$ for State $B$, thus decreasing the domestic supply in State A's labor market, the compensation paid to labor in State A may rise and give late movers incentives to continue to remain at home in order to take advantage of the improved compensation in the domestic labor market. Other built-in checks include sticky domestic obligations, such as patriotism or familial and/or other obligations.

\section{Economic Barriers}

The economic barriers to the liberalization of labor are intimately connected with the conceptual and psychological barriers discussed earlier in this Part. Those economic rationales are varied and wide-ranging. They include fear of the economic consequences of the liberalization of labor, protectionism for entrenched interests and an unconscious bias toward the benefits to be derived from and desirability of capital.

Principal among the feared economic consequences is the danger of downward wage equalization. ${ }^{131}$ The lowering of barriers to the movement of labor will, it is feared, expose domestic workers to competition which, through over-supply, will cause the compensation of labor in the broad domestic market to decrease. This fear appears to be valid but is both too narrowly focused and suffers from an overly short-term perspective. Domestic labor throughout the world already is exposed to competition. ${ }^{132}$ The contemporary model of trade liberalization allows capital to respond to the global competition among domestic labor markets through liberalized trans-border movement, but it prevents the majority of individual labor providers from doing so. Thus, capital may move jobs and entire production facilities at its discretion in response to fluctuating economic stimuli, such as, for example, taking advantage of lower wages in other domestic markets. ${ }^{133}$

The status quo advantages capital over labor. While capital may move in response to competition, capital may simultaneously impose lower wages on domestic labor by threatening to relocate as well as through hiring illegally present foreign-sourced labor with unequal legal status. Yet, for a very long time and until relatively recently, labor unions in domestic markets largely

131. See, e.g., Julian L. Simon, IMMIGRATION: THE DEMOgRaPhiC AND ECONOMIC FaCTS 4 (1995), available at http://www.cato.org/pubs/policy_report/pr-immig.html.

132. The cost-benefit economic analysis that leads to the erection of barriers to labor liberalization employs a very short time horizon.

133. Via outsourcing and closure of production facilities in State $A$ and reopening in State $B$. 
opposed the liberalization of labor. ${ }^{134}$ Two factors may explain that opposition. First, vested labor, thus far, has been able to maintain a superior compensation status vis-à-vis incoming labor; ${ }^{135}$ and organized labor may be employing a short-term and narrowly focused perspective that leaves it unaware of its impending potential obsolescence and irrelevance as it becomes unable to demand an equitable share of the benefits of production for labor. Second, the owners of capital have captured the dominant economic rhetoric and the penetration and persuasiveness of that rhetoric challenge the ability of the average worker to engage knowledgeably in the discussion regarding whether it is more advantageous for labor to be less well-compensated in situ or to be unemployed. The reverberation effects of the closure of production facilities may be worse for the domestic economy as a whole than would be a decline in compensation resulting from increased supply of labor to domestic markets. ${ }^{136}$

A final economic reason for the neglect of labor liberalization is related to the psychological and social fear of economic inundation. Will the infrastructure and social entitlement programs available to the citizens and nationals of State $A$ in State $A$ be overwhelmed by the demands of an influx of newly liberalized foreign-sourced labor? First, it would be possible to structure labor liberalization so as to limit access of foreign-sourced labor to such programs. ${ }^{137}$ Second, most economists agree that the positive echo

134. Following long years of anti-immigrant policies, labor unions in the United States have begun to change their position on this issue. The dwindling power of and decreasing participation in unions, among other things, have led to a reversal, such that organized labor now advocates pro-immigrant positions. See, e.g., JOHNSON, supra note 127, at 146-48. See also HAYTER, supra note 40 , at xxv; JULIE R. WATTS, IMMIGRATION POLICY AND THE CHALLENGE OF GLOBALIZATION: UNIONS AND EMPLOYERS IN UNLIKELY ALLIANCE 2-3 (2002) (describing and analyzing trade union response to immigration in the European Union). Like the nineteenth century anti-slavery campaigns in Britain supported by the developing British working class, this change in labor union policy is an example of the operation of Professor Derrick Bell's interest convergence theory. See Karen E. Bravo, Exploring the Analogy between Modern Trafficking in Humans and the Trans-Atlantic Slave Trade, 25 B.U. J. INT'L L. 207, 243 n.182 (2007).

135. See, e.g., Uchitelle, supra note 39.

136. Substantive labor rights, pensions and health care plans created quasi-property rights of labor in the product of its labor, and forced capital to share with labor the benefits of economic production. Those quasi-property rights have been successively trimmed through the diminution in the status of labor unions and other bargaining collectives. For example, through concessions from unionized workers, U.S. car companies offer lower compensation and benefits to newly hired employees. Id.

137. Creative use of provisions that link certain benefits to immigration status and economic status would decrease some of these anticipated demands. Such tactics have already been deployed in the United States. See, e.g., Howard F. Chang, Migration as International Trade: The Economic Gains from the Liberalized Movement of Labor, 3 UCLA J. INT'L L. \& FOREIGN AFF. 371, 391-92 (1998) (discussing the restricted access of immigrants to U.S. social entitlement programs). See also JOHNSON, supra note 127, at 151. Such provisions do run 
effects of immigrant presence and consumer and other economic activities outweigh the costs imposed on society by immigrants. ${ }^{138}$ Further, contrary to popular perception, the presence of such foreign-sourced labor may facilitate the continued presence and competitiveness of production facilities in the host state (the United States, for example) that might otherwise have been subjected to trans-border relocation. ${ }^{139}$ While there is no definitive determination of the positive or negative net fiscal effects of increased immigration, most professional economists tend to believe that the positive flows outweigh the costs. ${ }^{140}$

Finally, nativist protectionism underlies the economic arguments-the reluctance to confer to outsiders access to the economic benefits of the domestic labor market. That protectionism is both shortsighted and counterproductive and fails to acknowledge the vibrancy and positive aspects for economies that have access to and utilize a mobile labor force.

\section{E. Political Barriers}

The political barriers to the liberalization of labor in the context of trade liberalization are intertwined with the conceptual, social, psychological and economic barriers. The very structure and nature of the world's organization into nation-states, with dominating fundamental concepts of sovereignty, nation-state nationalism and concepts of citizenship and belonging, as well as the denial and political cowardice of leaders, are some of the contributing political factors that lead to the neglect of labor liberalization within the broader trade liberalization project. Labor liberalization is unthinkable and off the table because it is thought that its benefits may not accrue to those within the borders of more powerful states, while the world's political organization into states imposes limited obligations on individual states toward non-citizens outside their borders.

That borders are artificial, that states are artificial constructs created and maintained for efficiency of organization and resource harnessing on a

counter to liberal traditions of welcoming the Other. See SEYLA BEHHABIB, THE RIGHTS OF OTHERS: ALIENS, RESIDENTS, AND CITIZENS $4-6$ (2004); Joseph H. Carens, Aliens and Citizens: The Case for Open Borders, 49 REV. OF POL. 251, 259-60 (1987).

138. See, e.g., SIMON, supra note 131, at 3-4;Borjas, supra note 128, at 1698; Angela M. Kelley, The Economic Impact of Immigration, IMMIGRATION DAILY, http://www.ilw.com/ articles/2008/0107-Kelley.shtm. In the United States, the positive contributions include payments into social security funds with limited possibility of later access, payment of taxes through the fraudulent use of existing Social Security numbers and rejuvenation of abandoned neighborhoods. See, e.g., JOHNSON, supra note 127 , at 139-40.

139. JOHNSON, supra note 127, at 148-49.

140. See, e.g., Kelley, supra note 138. See also David Card, Keynote Address at the Federal Reserve Bank of Philadelphia Research Event: Is the New Immigration Really So Bad? (Apr. 29, 2005), available at http://www.philadelphiafed.org/econ/conf/immigration/card.pdf. 
naturally borderless globe impinges little on public political conceptions. The political organization of the globe into nation-states focuses political interests within constructed borders and toward the mechanisms that will protect the interests of those within the borders. Political energies then are directed toward border protection and enforcement and toward benefiting those things and people internal to the border while defending against the external or attempting to mold the external to create advantages for internal interests. ${ }^{141}$ The constructed artificiality of states has become the overwhelming default reality, and global interests are often neglected. ${ }^{142}$

Working from that constructed reality and hampered by nation-state borders, politicians and the polity concentrate on sovereign prerogatives, the defense of borders and narrow domestic interests. Lost is the fact that borders are endlessly porous, that the globe is a unit, and that even the circumscribed trade liberalization model undertaken thus far has already integrated domestic economies into a global whole. ${ }^{143}$

The political competition against the trans-border Other may impoverish both State $A$ and State $B$, even though collaboration might have brought greater shared prosperity. As noted in the context of economic causes of the lack of labor liberalization, ${ }^{144}$ the irony is that failure to liberalize labor redounds to the detriment of those within the borders as well as those outside, while liberalization of labor would enlarge access to the benefits of trade liberalization to a larger number of beneficiaries. ${ }^{145}$ For example, to post-

141. HAYTER, supra note 40, at 151-52 ("Most of the arguments for and against immigration controls are expressed in terms of the interests of nations and their current inhabitants, rather than of the peoples of the world as a whole.").

142. See, e.g., Willem van Schendel \& Itty Abraham, Introduction: The Making of lllicitness, in Illicit Flows and Criminal Things: STATES, BORDERS, AND tHE OTHER Side OF GLOBALIZATION 5 (Willem van Schendel and Itty Abraham eds., 2006).

Most social science is expressly and unconsciously bound by state boundaries, categories

that are reproduced within institutionally sanctioned academic specializations, e.g.,

Brazilian political science or the sociology of France. Hence, it is no surprise that the

field of knowledge that seeks to understand the world beyond the state, international

relations, nonetheless takes the state as its foundational unit of analysis.

Id. Examples of issues that require a more global perspective and that have become more clear and urgent include the environment (water and air), food sources and energy.

143. The U.S. mortgage crisis, global oil prices, food scarcity and tainted drugs and toys are only the most extreme examples of the contemporary interdependence of domestic economies. See, e.g., Keith Bradsher, From Six-Year Drought in Australia, a Global Crisis Over Rice, N.Y. TimES, Apr. 17, 2008, at A1; Paul Krugman, Grains Gone Wild, N.Y. TimES, Apr. 7, 2008; Jad Mouawad, Rapidly Rising Global Demand for Oil ls Provoking New Energy Crisis, N.Y. TIMES, Nov. 9, 2007, at A24.

144. See supra Part IV.D.

145. In the European Union, the populations of individual member states, as well as individual domestic economies, have enjoyed economic growth and greater prosperity as a result 
WWII Germany and France the benefits of increased integration were greater economic prosperity and stability for both states as well as the diminution, through the mechanisms of greater interaction and interdependence, of transborder hostility between those two states and within the rest of Europe. Familiarity and interdependence can breed tolerance.

The nation-state's reification of the border and the illusion of border control limit political and economic vision. Political cowardice prevents policymakers from leveling with their polity and acknowledging that trade liberalization is inevitably integrative; that transformation of the society's economy is beyond the state's ability to control; and that the challenges and costs of trade liberalization are already here. The open questions are whether and when those costs will be recognized and to what or whom they will be attributed. Politicians and policy makers attempt to deny or disregard the short-term costs of trade liberalization while, at the same time, emphasizing the long-term benefits and failing to ease the transition pains of those who are negatively affected. Further, there is little open discussion regarding the costs of not pursuing real trade liberalization. What benefits would attempted economic isolation achieve? Even if the overwhelming trend toward trade liberalization could be reversed without wholesale economic and other disruption, the prosperity of countries which attempt to return to autarkic production would be severely decreased.

Further, in the United States, for example, there is widespread failure to openly acknowledge that some of the regional trading arrangements are driven by political - that is, power retention, demonstrations of political support, and influence gathering - considerations of the executive, rather than by immediate
economic concerns. ${ }^{46}$

Finally, the profound inability to look beyond nation-state lenses and the neglect of labor liberalization may reveal deep skepticism regarding the fundamental theories of trade liberalization. That neglect undermines access to the benefits of trade liberalization for the vast majority of the world's economic actors and would-be beneficiaries.

\section{PART V-EXPERIMENTING WITH LABOR LIBERALIZATION NOW? PROSPECTS FOR THE FUTURE}

Now is the time to liberalize labor as part of the broader global liberalization of trade. Failure to do so betrays fundamental concepts of both

of freedom of movement and the ability to respond to labor market opportunities throughout the Union.

146. The free trade agreements that the United States has executed with Israel, Jordan and Chile serve as examples. The texts of these treaties are available from the web site of the U.S. Trade Representative. See Office of the United States Trade Representative, http://www.ustr.gov/ Trade_Agreements/Section_Indes.html (last visited Oct. 10, 2008). 
classical and neoclassical economics and of the theory of comparative advantage on which the contemporary trade liberalization project is based.

Transnational labor market competition is inevitable and already is a fettered reality. The question is whether capital alone will continue to be liberalized and permitted to arbitrage the differences in wage levels or whether labor will be liberalized to take advantage of those opportunities as well. The status quo allows capital to price discriminate with respect to how much labor can and will be compensated. The effect of that price discrimination is to create incentives for the movement of labor from one state to another in search of higher compensation. However, when that labor crosses the border outside of the legal and regulatory contexts created and maintained by the host and home states, that labor may be condemned to quasi-personhood within the host state. That quasi-personhood permits the creation and maintenance of exploitative relationships between labor and consumers of labor. That very exploitation then undermines the substantive protections of the capital-labor relationship that were either created by and/or were to be protected pursuant to the RTA agreement. ${ }^{147}$

Further, the failure to liberalize labor in the face of economic forces that compel the unsanctioned movement of labor across borders consigns mobile labor to an unequal status vis-à-vis both capital and domestic (host state) labor. The consequences for domestic labor may include both less effective enforcement of labor standards as well as a decrease in compensation as the foreign-sourced labor accepts lower compensation from capital than would be demanded by similarly employed domestic labor.

\section{A. Effects of Failure to Liberalize Labor}

\section{On RTAs Generally}

The trade distortive effects of the failure to liberalize labor within the context of regional trade arrangements concentrate and lengthen the transitional periods following the implementation of trade liberalization. The distortive effects, also present in the context of multilateral trade liberalization, are more highly concentrated within RTAs. Labor that is prevented from responding to the economic incentives and forces stimulated by liberalization of other factors of production may be forced to respond through either intrastate or trans-border movement despite the lack of legal sanction for such movement. The omission of labor from the trade liberalization arsenal neither preserves the level of compensation of labor in higher-wage markets (i.e., does

147. See, e.g., supra text accompanying note 104 (discussing the efforts within the CARICOM, MERCOSUR, NAFTA and DR-CAFTA regimes to maintain existing labor standards). 
not prevent downward wage equalization) nor facilitates the upward movement of wage levels in the lower-wage member state. ${ }^{148}$ This effect undermines a key purpose of the formation of RTAs: the improvement of standards of living of domestic labor through increased trade volumes, economic activity and employment levels.

\section{On RTAs in the Western Hemisphere}

That betrayal of both trade liberalization theory and free market principles contributes to transition pains and inadequate dissemination of the benefits anticipated from regionalism. The specific effects of the neglect of labor liberalization in the Western Hemisphere include increased flows of illegal migration ${ }^{149}$ and a decline in substantive labor standards. Using the example of NAFTA, for example, it is clear that despite the would-be protective effects of the NAALC (NAFTA side agreement), labor protection standards in the workplace have declined in the United States. The Supreme Court's opinion in Hoffman Plastics, which withheld substantive labor law protections from undocumented employees, ${ }^{150}$ may serve to effectuate a further loosening and lowering of the labor standards to which employers in the United States must adhere. ${ }^{151}$ Examples from the two other NAFTA parties include the Abscal Plan introduced in the Mexican Congress, which would "flexibilize" Mexico's federal labor law, ${ }^{152}$ and the decision by the Canadian province of British

148. The downward movement in the compensation of U.S autoworkers is a quintessential example. Uchitelle, supra note 39.

149. One example is the flow of labor between the United States and Mexico as a result of NAFTA. Anecdotal evidence suggests the same for CARICOM and MERCOSUR. The prospects are similar for DR-CAFTA, since DR-CAFTA's labor immobility goals and provisions are even stronger than those of the NAFTA Agreement.

150. Hoffman Plastic Compounds v. NLRB, 535 U.S. 137, 151-52 (2002).

151. Maria Pabon Lopez, The Place of the Undocumented Worker in the United States Legal System After Hoffman Plastic Compounds: An Assessment and Comparison with Argentina's Legal System, 15 IND. INT'L \& COMP. L. REV. 301 (2005). The nation-state blinders that constrain the courts lead them to undermine the very interests (safety of domestic workers) that they purport to protect. The difficulty of reaching a negotiated consensus on applicable labor standards, the disparate analyses that would be applied by domestic courts and the limited enforcement powers of international standard-setting bodies mean that it is unlikely that a transnational standard-setting mechanism, standing alone, would create the benefits to labor that could be achieved through labor liberalization. Instead, standard setting, maintenance and enforcement must work in tandem with the liberalization of labor. The transnational labor citizenship suggested by Professor Jennifer Gordan is one potential mechanism for facilitating labor liberalization while maintaining labor standards. See Jennifer Gordon, Transnational Labor Citizenship, 80 S. CAL. L. REV. 503, 561-78 (2008).

152. A NAALC complaint was filed against Mexico in response to the proposed changes. U.S. NAO Public Submission US 2005-01, U.S. DEPT. OF LABOR, Feb. 17, 2005, https://www.exchange.iu.edu/owa/attachment.ashx?attach=1 \&id=RgAAAAA0hLJNHEMGRrDj D471 IaeCBwD 1 2wC0EtmRrNP3Fj0\%2facQAAAAO02KAAD4QoKsx9COTqr0XdQkw5leAB 
Columbia to close down the Human Rights Commission that administered the province's labor law standards. ${ }^{153}$

\section{B. RTAs Provide Excellent Opportunity for Experimentation}

Regional trading arrangements provide excellent opportunities for experimentation. Firstly, RTAs are free to experiment with labor liberalization as "trade in labor" because labor is not a subject of the GATT. Participants in a regional trading arrangement would not violate their GATT obligations if labor were to be liberalized under the RTA agreement. ${ }^{154}$

Secondly, the opportunity to experiment with labor liberalization among RTAs would function as training wheels for multilateral liberalization. ${ }^{155} \mathrm{~A}$ quintessential example of the migration of trade liberalization principles from the regional to the multilateral sphere is the adoption of the TRIPS Agreement as one of the obligatory multilateral agreements entry into which is required of WTO Member States. ${ }^{156}$ Many of the provisions of the TRIPS Agreement were negotiated and adopted in the context of the NAFTA and introduced into the Uruguay Round. ${ }^{157}$

A third factor that militates in favor of experimenting with labor liberalization in the context of RTAs is the interplay of geographic proximity (enjoyed by a majority of the member states in all four of the RTAs discussed in this Article (CARICOM, MERCOSUR, NAFTA, DR-CAFTA)) with the enhanced homogeneity of political, economic and social circumstances that stem from often intertwined histories of participation in or subjection to shared experiences. For example, the member states of MERCOSUR and CARICOM have shared experiences of colonization and enslavement, among other historical forces, together with significant informal intra-regional movement of labor. This homogeneity and geographic proximity (enhanced by geographic

11z4a4AAAJ\&attid0=EAC5fkw0c07YTqeC0biJbZ9w\&attcnt=1. See Michal Kohout, The New Labor Law Culture and Labor Law Reform in Mexico, 35 LATIN AM. PERSPECTIVES 135 (2008) (analyzing labor law reform in Mexico).

153. The Swift Demise of B.C.'s Human Rights Commission, NAT'L UNION OF PUB. AND GEN. EMPLOYEES, Nov. 18, 2002, http://www.nupge.ca/news_2002/news_no02/n18no02a.htm.

154. Pursuant to Article $\mathrm{V}$ of the GATS, labor market integration may be a proper subject of a regional trading arrangement. GATS, supra note 28 , art. V. Moreover, the provision is permissive only and does not appear to impose any hard obligation on the participants. Id. Therefore, RTAs that experiment with labor liberalization are unlikely to violate their GATT obligations.

155. Much in the way that it is claimed that RTAs may prepare states for accession to the WTO. See Sungjoon Cho, Breaking the Barrier Between Regionalism and Multilateralism: A New Perspective on Trade Regionalism, 42 HARV. INT'L L.J. 419, 423-35 (2001).

156. TRIPS agreement, supra note 19.

157. Compare, NAFTA, supra note 61, art. 1701, § 2, with TRIPS Agreement, supra note 19 , at 85 . 
contiguity) may facilitate the management of the logistics of labor liberalization and of the transition pains that may come from the pressure to openly integrate the labor markets. With respect to smaller RTAs, such as CARICOM, the movement of labor would be less unwieldy due to the smaller scale of the populations at issue. The smaller scale would also lessen the challenges of the expected disruption during the necessary transition phases.

A potential drawback of labor liberalization within the context of RTAs is one that is shared with all other aspects of trade liberalization within RTAs: liberalization of any additional factor of production may further strengthen the trade diversion forces and pressures already attributed to RTAs. ${ }^{158}$ This potential drawback, however, does not negate the prospective benefits of experimenting within RTAs. So long as states continue to be leery of adding labor liberalization to the broader multilateral trade liberalization enterprise under the auspices of the WTO, RTAs remain the second best (and perhaps even the best) alternative for controlled experimentation. In addition, since other trade diversion consequences already may be in effect as a result of the proliferation of RTAs, it is unclear that the trade diversion consequences that would stem from labor liberalization would significantly worsen those that may exist as a result of other aspects of trade liberalization within RTAs.

\section{Existing Examples of Successful Experimentation}

The European Union and federal states such as the United States, Canada and Germany provide extant examples of experimentation with labor liberalization. Throughout the United States, Canada and Germany, each of which is a federal state, labor may move without hindrance in search of productive economic activities or for other reasons. The introduction of freedom of movement within the European Union as part of the Four Freedoms aimed at the creation of a single market ${ }^{159}$ has allowed the freer movement of individuals. The examples provided by these political entities demonstrate that labor liberalization which is provided for within those contexts results in some dislocation, but also allows for swifter responses to economic stimuli. ${ }^{160}$

Opportunities for experimentation are not irrevocably lost. While perhaps overwhelmingly difficult in the multilateral context due to the larger number of

158. The debate regarding the trade-diversion or trade-promotion effects of RTAs has elicited a great deal of scholarly thought. See, e.g., Jagdish Bhagwati, Preferential Trade Agreements: The Wrong Road, 27 LAW \& POL'Y INT'L BUS. 865, 866 (1995) (introducing the term "preferential trading agreements" to encompass all types of regional trading arrangements).

159. See, e.g., BHALA \& KENNEDY, supra note 3, at 215-21.

160. For example, in the United States, the citizens of Oklahoma who were devastated by the dust storms of the early twentieth century were able to move legally and freely to other states in search of economic opportunity. That movement facilitated the economic recovery of Oklahoma and contributed to the economic growth of states who received the interstate economic migrants. 
interests represented at the negotiating tables, within regional trading arrangements opportunities to experiment would be facilitated by courageous economic theoreticians and politicians, and the expansion of conceptual frameworks surrounding issues of sovereignty, global versus nation-state interests, and the nature of membership and "Other-"ness in the polity. In tandem must come the education of the polity to adopt a non-blinkered reality and the acknowledgement of the true short-term costs and benefits of the distortive choices of the existing half- and hard-hearted trade liberalization.

\section{Labor Liberalization Now?}

Labor liberalization would expand access to the benefits of trade liberalization to include a wider range of economic actors, including both sending and receiving states. The free movement of labor would more closely integrate labor-rich economies into the global economy, more widely disperse the benefits of trade liberalization and acknowledge the already vibrant and irrevocable interdependence among domestic economies. With labor liberalization, labor-rich states would be permitted to flexibly supply the labor demands of the global market by specializing in and exploiting their comparative advantage, but on terms that are more beneficial to the individuals and groups who provide that labor. Further, closer integration of labor-rich and labor-poor economies will facilitate, rather than impede, democratized access to the economic opportunities and stimuli unleashed by globalization.

The distortive effects of the neglect of labor liberalization contribute to severe human rights abuses that arise from the easily exploited conditions of labor that moves in response to economic forces but whose movement is not sanctioned by states. ${ }^{161}$ To liberalize labor is to decrease the opportunities for exploitation that arise from the "illicit" movement of labor responding to trade liberalization forces. Included on the spectrum of exploitation may be the price discrimination practiced by capital, which handicaps labor vis-à-vis capital as both factors of production compete and collaborate in the global marketplace. In the current model, mobile capital is able to seek out evercheaper involuntarily immobile labor for exploitation, while that labor is largely prevented from responding to cross-border economic stimuli.

161. See, e.g., Anna Zalewski, Note, Migrants for Sale: The International Failure to Address Contemporary Human Trafficking, 29 SUFFOLK TRANSNAT'L L. REV. 113 (2005). See also Rutvica Andrijasevic, The Difference Borders Make: (Il)legality, Migration and Trafficking in Italy Among Eastern European Women in Prostitution, in UPROOTINGS/REGROUNDINGS: QUESTIONS OF HOME AND MIGRATION 251, 262 (Sara Ahmed et al. eds., 2003) (stating that European Union border protection and anti-immigrant policies and methodologies "work in favour of third parties who organize trafficking, whether individuals and agencies, because they become a kind of supplementary migration system ..."). 
Further, despite state reluctance to make multilateral or regional commitments or enter into negotiations about the liberalization of labor, the trans-border trade in labor already exists and states, individuals and criminal enterprises are active participants. Examples include the recruitment of skilled workers (for example, doctors and nurses from African nations to the United Kingdom and other parts of the developed world ${ }^{162}$ and the recruitment of teachers from the Caribbean by the New York City school system ${ }^{163}$ ) and unskilled labor (for example, the use of the $\mathrm{H}-2 \mathrm{~A}$ and $\mathrm{H}-2 \mathrm{~B}$ visas in the United States to satisfy seasonal demands for labor). ${ }^{164}$ Other examples include the construction of economic development models dependent upon the transborder trade in human capital, such as the recruitment of skilled and unskilled labor from South Asia (Pakistan ${ }^{165}$ and the Philippines ${ }^{166}$ ) to the Gulf States and the developed world.

162. See, e.g., Daniel Morris, Giving Aid with One Hand, Taking MDs with the Other, TheStar.com, Aug. 7, 2007, http://www.thestar.com/printArticle/243777; MALAWI: Donors and Govt Pool Funds Against Brain Drain, IRIN, May 28, 2007, http://www.irinnews.org/ Report.aspx? ReportId=72414.

163. See, e.g., Regional Education Ministers to Discuss Teacher Recruitment, JAMAICA OBSERVER, May 27, 2002, available at http://www.jamaicaobserver.com $/$ news $/ \mathrm{html} / 20020526 \mathrm{t} 2$ 20000-0500_26159_obs_regional_education_ministers_to_discuss_teacher_recruitment.asp;

Commonwealth Countries Reach Agreement on Teacher Recruitment, JAMAICA OBSERVER, Sept. 8, 2004, available at http:/www.jamaicaobserver.com/news $/ \mathrm{html} / 20040907 \mathrm{t} 200000-0500 \_658$ 84_obs_commonwealth_countries_reach_agreement_on_teacher_recruitment .asp.

164. See, e.g., SOUTHERn POVERTy LAW CENTER, Close to Slavery: GuestWorker PROGRAMS IN THE UNITED STATES (2006), http://www.splcenter.org/pdf/static/SPLCguest worker.pdf; DAVID GRIFFITH, AMERICAN GUESTWORKERS: JAMAICANS AND MEXICANS IN THE U.S. LABOR MARKET 45-75 (2006) (describing the extensive U.S. seasonal agricultural and services guestworker labor programs and the endemic abuses and exploitation of the workers).

165. See, e.g., The Overseas Employment Corporation of Pakistan, http:/www.oec.gov.pk/ english/en_index.php (last visited Oct. 10, 2008) (overseeing the export of labor from Pakistan). See also Graeme Hugo \& Charles Stahl, Labor Export Strategies in Asia, in INTERNATIONAL Migration: Prospects and POlicies in a Global Market 174-97 (Douglas S. Massey \& J. Edward Taylor eds., 2004) (discussing the labor export development strategies of a number of Asian states).

166. See Jason DeParle, A Good Provider Is One Who Leaves, N.Y. Times MaGazinE, Apr. 22,2007 , at 53. The trade pact recently executed by the governments of the Philippines and Japan provides for limited liberalization of the movement of skilled labor between the two countries. Japan, Philippines Sign Free-Trade Agreement, THE JAPAN Times OnLIne, Sept. 10, 2006, available at http://search.japantimes.co.jp/cgi-bin/nn20060910a2.html (noting that "a limited number of Filipino nurses and caregivers who meet certain qualifications designated by Manila will be allowed to work in Japan, on condition they pass Japanese examinations or graduate from specified training facilities in Japan"). However, the trade agreement has not yet been ratified by the Philippine Senate. Japan Agrees to Amend Trade Treaty, MANILA STANDARD TODAY, June 18, 2008, at Al, available at http://www.manilastandardtoday.com/ ?page=news4_june18_2008. 
In addition, the contemporary massive global migration flows, while partly due to the flow of refugees from conflict situations, is largely composed of economic migrants who evidence labor's attempt to respond productively to global economic forces. Often, however, labor is foreclosed from responding in accordance with existing law. Labor's response is deemed illegal by the interposition of nation-state-centered domestic law between human economic actors and transnational economic forces. Labor liberalization would confer legally recognized and enforceable autonomy-freedom of movement ${ }^{167}$ - to labor as labor seeks to respond to market forces. Surely that response is a fundamental manifestation of free market theory.

Finally, people, too, are economic actors, as are states and other legal entities, such as corporations and other profit-seeking legal entities. Labor liberalization will create more choices for human labor as autonomous economic actors as labor i.e., humans, are re-conceptualized as integrated economic actors-not merely cabined into silos as labor or consumers or humans beings.

The potential for sizeable infrastructure costs suggests that labor liberalization should be gradually implemented in order to put in place and test the shock absorption mechanisms of particular states. Some implementation issues not addressed here and left for future exploration include, for example, the logistics of transition, such as gradual sectoral implementation of labor liberalization and/or initial limitation of liberalization of labor to selected categories of labor that are more responsive to immediate market demands. Other issues include adoption of trans-border credentials recognition, negotiation of eligibility for and rights to social entitlements, and the avoidance of the creation of second-class status for foreign-sourced labor through the provision of avenues for legal permanent residence and participation in the polity. The decades-long efforts of the European Union in this area, while by no means perfect, may provide useful models for implementation.

167. The freedom of movement currently recognized in international human rights instruments protects movement in two of three senses only-movement within the native state, and movement out of the native state, but not movement into a new state. See International Covenant on Civil and Political Rights, art. 12, 6 I.L.M. 372 (1967) (recognizing individual freedom of movement within countries and the right to leave the territory of any country, but no right to enter a country of which the individual is not a citizen). 


\section{PART VI}

\section{CONCLUSION-THE WAY FORWARD}

Trade liberalization inevitably leads to de facto integration of economies. $^{168}$ Globalization and its engine, trade liberalization, unleash integrative processes, despite the best efforts and short-sightedness off its wielders. Confinement of trade liberalization to the movement of goods, capital and services attempts to deny the inchoate and irrepressible integrative processes integral to globalization and trade liberalization. ${ }^{169}$

The geographic proximity of member states and other pre-existing interrelationships increases interdependence and integration of the member states of regional trade arrangements. Further, by its very nature, as a result of the economic forces that it unleashes, trade liberalization constitutes a built-in challenge to state sovereignty and mastery over state territory.

Failure to liberalize labor, a key factor of production, is distortive and leads to flows of undocumented labor seeking to respond to the integrative and transformative pressures of the unleashed economic forces. The failure to acknowledge labor's status as a mobile factor of production and independent subject of trade liberalization signals that trade liberalization, instead of deployment as a tool for conferring benefits to a wide range of economic actors, is instead being used to maintain the power-subordination status of existing players.

In order to mold the institutions and processes of globalization to maximize welfare enhancing benefits, policy makers need to adopt a leap of perception from that of nationality- and border-based us-versus-them to one of common humanity and global interests. This leap would entail the development of a global viewpoint and interest protection, as opposed to statecentered ones, together with extreme political courage and honesty about economic realities and the causes and effects of the transformations stimulated and fostered by trade liberalization. In turn, from individual polities, such telling and accepting would require societal courage and transformation.

168. Economies are just as integrated as are the environment, climate and other factors; states and borders are the anomalies. See Bradsher, supra note 143; Krugman, supra note 143; Mouawad, supra note 143.

169. The essentially integrative aspects of trade liberalization may have been concealed by the long period of stasis (the Cold War) that followed the Bretton Woods process. 
